\title{
The brain of teleost fish, a source, and a target of sexual steroids
}

\author{
Nicolas Diotel ${ }^{1}$, Jean-Luc Do Rego ${ }^{2}$, Isabelle Anglade ${ }^{1}$, Colette Vaillant ${ }^{1}$, Elisabeth Pellegrini ${ }^{1}$, \\ Hubert Vaudry ${ }^{2}$ and Olivier Kah ${ }^{1 *}$ \\ Neurogenesis and CEstrogens, UMR CNRS 6026, IFR 140, Université de Rennes 1, Rennes, France \\ 2 Différenciation et Communication Neuronale et Neuroendocrine, INSERM U982, PRIMACEN, IFRMP 23, Université de Rouen, Mont-Saint-Aignan, France
}

\section{Edited by:}

Kazuyoshi Tsutsui, Waseda University,

Japan

Reviewed by:

Barney A. Schlinger, University of California at Los Angeles, USA

Eric W. Roubos, Radboud University

Nijmegen, Netherlands

${ }^{*}$ Correspondence:

Olivier Kah, Neurogenesis and CEstrogens, UMR CNRS 6026, Case

1302, Campus de Beaulieu, 35042

Rennes, France.

e-mail: olivier.kah@univ-rennes1.fr
Neurosteroids are defined as steroids de novo synthesized in the central nervous system. While the production of neurosteroids is well documented in mammals and amphibians, there is less information about teleosts, the largest group of fish. Teleosts have long been known for their high brain aromatase and $5 \alpha$-reductase activities, but recent data now document the capacity of the fish brain to produce a large variety of sex steroids. This article aims at reviewing the available information regarding expression and/or activity of the main steroidogenic enzymes in the brain of fish. In addition, the distribution of estrogen, androgen, and progesterone nuclear receptors is documented in relation with the potential sites of production of neurosteroids. Interestingly, radial glial cells acting as neuronal progenitors, appear to be a potential source of neurosteroids, but also a target for centrally and/or peripherally produced steroids.

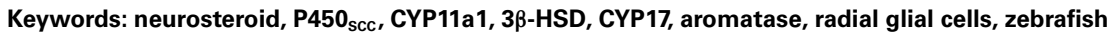

\section{INTRODUCTION}

Similar to that of other vertebrates, the brain of teleost fishes is a target organ of sex and adrenal steroids whose effects have been examined mainly in the context of the neuroendocrine control of reproduction (Zohar et al., 2009). However, while pioneer studies documented some 30 years ago that the brain of adult fish exhibits unusually elevated aromatase and $5 \alpha$-reductase activities (Callard et al., 1978), it is only until the last few years that the capacity of the teleost brain to produce true neurosteroids received some attention. As a result, very little is known regarding the activity and/or sites of expression of other steroidogenic enzymes, notably those involved in sex steroid synthesis: CYP1la1 (cytochrome P450 side chain cleavage), CYP17 (P450 $17 \alpha$-hydroxylase/c17,20 lyase), $3 \beta$-HSD (3 $\beta$-hydroxysteroid dehydrogenase), 17 $\beta$-HSD (17 $\beta$-hydroxysteroid dehydrogenase), and $5 \alpha$-reductase. In contrast, aromatase that ensures the conversion of androgens into estrogens, has been the focus of intense research which has been reviewed recently (Diotel et al., 2010a). As a consequence, the question remained open as to the central or peripheral origins of aromatizable androgens used as substrates for brain aromatization (Diotel et al., 2011a). This article aims at reviewing the current situation regarding steroidogenesis in the brain of fish and, in particular, highlights the fact that radial glial progenitors (Pellegrini et al., 2007), which persist in the brain of adult teleosts, can be privileged sources and targets for neurosteroids.

\section{PRELIMINARY REMARKS REGARDING TELEOST FISH}

A common misconception is the idea that fish are ancestors to tetrapods. While this is true for ancestral fish, it is wrong when it comes to the largest group of fishes, the teleosts, which comprise around 30,000 species and include most commercially important fish or model species such as the medaka or the zebrafish. In fact, teleosts belong to the Actinopterygian lineage that separated from the Sarcopterygians some 450 million years ago. While Sarcopterygians, fish with lobed fins, were able to get out of the water to give birth to primitive tetrapods, early Actinopterygians (ray-fined fish) remained in the water and diversified to finally give rise to the enormous group of teleost fishes. Thus, while teleosts share $70 \%$ of their genome with mammals, they diverged from tetrapods long time ago and thus present some peculiarities that we intend to highlight in this review.

Another important aspect that also needs to be clarified from the beginning is that, although fish share with tetrapods a number of steroidogenic enzymatic pathways, biologically active compounds are not necessarily exactly the same or do not sustain identical functions according to sex. For example, testosterone is not a male-specific androgen in teleosts where $\Delta 411$-oxygenated androgens are acknowledged as the main androgenic steroids mediating male-specific functions or behavior. These androgens, such as 11oxo-testosterone $(11 \mathrm{KT})$ or 11beta-hydroxy-androstenedione, are derived from testosterone and androstenedione $(\Delta 4)$ after conversion by $11 \beta$-hydroxylase (CYP11B), $11 \beta$-hydroxysteroid dehydrogenase (11 $\beta$-HSD), and 17 $\beta$-HSD. Similarly, teleost fishes possess unique progestagens, such as $17 \alpha, 20 \beta$-dihydroxyprogesterone, which plays major functions in final oocyte maturation, meiosis resumption, and sexual behavior.

Another important feature of teleosts is that they experienced an additional whole genome duplication unlike other tetrapods. This duplication, often referred to as 3R (Ravi and Venkatesh, 2008), occurred some 320-350 million years ago. By generating a large number of extra genes, it is believed that $3 \mathrm{R}$ has contributed to the rapid speciation and diversification of teleosts. As a result, fish often have duplicated genes and this is, among others, the case of genes of importance for this review such as 
cyp19a1 encoding aromatase or estrogen receptor beta $\beta$ (ER $\beta$ or esr $2 a)$.

Finally, it must be stressed out that the adult fish brain differs from the mammalian one by its very active ubiquitous neurogenesis (Ekström et al., 2001), which is supported by persisting radial glial cells (RGC; Pellegrini et al., 2007). Furthermore, as described below, aromatase is only expressed in such radial progenitors, which may also express other steroidogenic enzymes. Thus, a potential function of neurosteroids in fish brain could be to modulate this neurogenic process.

\section{DE NOVO STEROID SYNTHESIS IN THE BRAIN OF TELEOSTS AROMATASE ACTIVITY}

In teleost fishes, studies in the 1980s first documented the presence of high aromatase and $5 \alpha$-reductase activities in the brain of adult goldfish (Carassius auratus) and toadfish (Opsanus tau) of both sexes. These activities vary according to the sex cycle, and steroid treatments were consistently shown to increase aromatase activity (Pasmanik and Callard, 1985, 1988; Pasmanik et al., 1988). The occurrence of a high aromatase activity was confirmed in many teleost species (Pasmanik and Callard, 1985, 1988; Borg et al., 1987a,b; Timmers and Lambert, 1987; Timmers et al., 1987; Andersson et al., 1988; Mayer et al., 1991; Gonzalez and Piferrer, 2002, 2003; Piferrer and Blazquez, 2005) and was later found to correspond to expression of a brain-specific aromatase form, brain aromatase, generated by one of two duplicated cyp19a1 genes (see below). The most detailed information was obtained in the European sea bass showing that brain aromatase has a high affinity for androstenedione and that the brain maximum reaction rate ( $V$ max: $7.8 \mathrm{pmol} / \mathrm{mg}$ protein $/ \mathrm{h}$ ) was four times higher $(P<0.001)$ than the ovarian one $(2.1 \mathrm{pmol} / \mathrm{mg}$ protein $/ \mathrm{h}$; Gonzalez and Piferrer, 2002, 2003).

In the brain of African catfish, the distribution of aromatase activity was studied in more detail using punches $(0.3 \mathrm{mg}$ of tissue) taken from 500- $\mu$ m-thick transverse sections incubated with $\left[19-{ }^{3} \mathrm{H}\right]$-androstenedione. The highest activity $(3.7 \mathrm{pmol})$ was detected in the preoptic region, followed by the caudal hypothalamus and the telencephalon (2.5 pmol; Timmers and Lambert, 1987; Timmers et al., 1987). Similar activities (2.3 pmol) were found in the most rostral part of the telencephalon and the dorsal part of the mesencephalon, i.e., in the tectum opticum and torus semicircularis. A moderate aromatase activity was observed in other parts of the brain, except for the cerebellum and hindbrain, in which aromatase activity was hardly detectable $(0.1-0.3 \mathrm{pmol})$. As detailed below, these data match closely the distribution of brain aromatase mRNA and protein.

\section{METABOLIC ACTIVITY OF OTHER STEROIDOGENIC ENZYMES}

More recently, $3 \beta$-HSD activity was reported in the brain of adult zebrafish (Sakamoto et al., 2001; Diotel et al., 2011a). Biochemical studies combined with HPLC analysis showed that the zebrafish brain converts pregnenolone into progesterone, indicating $3 \beta$-HSD enzymatic activity. This activity could be substantially inhibited by $10^{-4} \mathrm{M}$ trilostane, a specific inhibitor of $3 \beta$-HSD (Sakamoto et al., 2001). In another recent study, zebrafish brain extracts were incubated with $\left[{ }^{3} \mathrm{H}\right]$-pregnenolone, resulting in the identification of aromatizable androgens and a

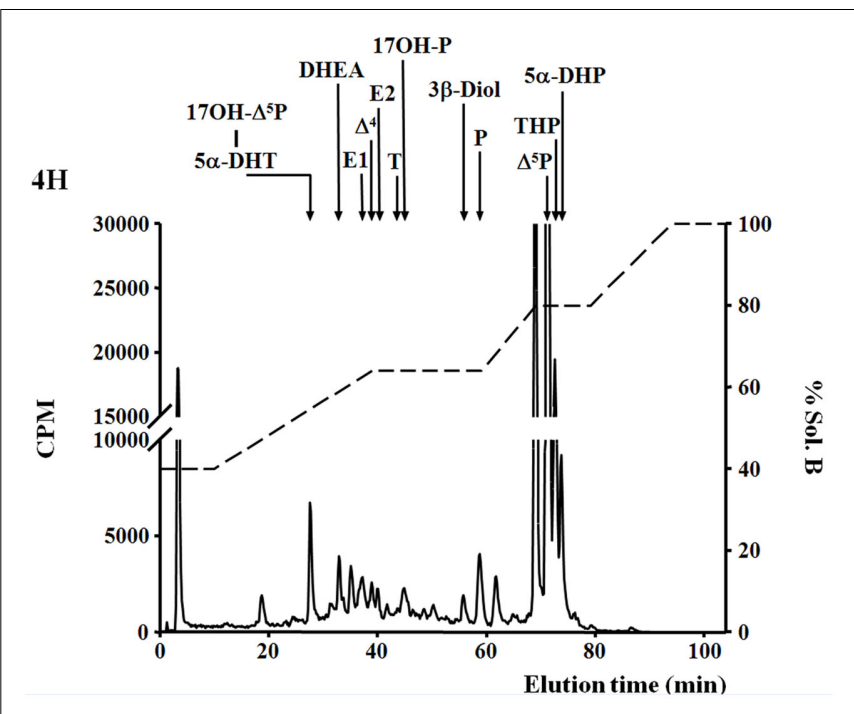

FIGURE 1 | De novo steroid synthesis by the brain of adult zebrafish. RP-HPLC analysis of radioactive steroids formed after a $4 \mathrm{~h}$ incubation of 14 adult zebrafish brains with $\left[{ }^{3} \mathrm{H}\right]$-pregnenolone $\left(\left[{ }^{3} \mathrm{H}\right]-\Delta^{5} \mathrm{P}\right)$. The ordinate axis indicates the radioactivity measured in the HPLC eluent. The dashed lines represent the gradient of secondary solvent (\% solution $B$ ). The arrows indicate the elution positions of standard steroids: $17 \mathrm{OH}-\Delta^{5} \mathrm{P}$,

17-hydroxypregnenolone; $5 \alpha$-DHP, $5 \alpha$-dihydro-progesterone; $5 \alpha$-DHT, $5 \alpha$-dihydro-testosterone; DHEA, dehydroepiandrosterone; $\Delta^{4}$, androstenedione; T, testosterone; $17 \mathrm{OH}-\mathrm{P}, 17$-hydroxyprogesterone; $\mathrm{P}$, progesterone; $\Delta^{5} \mathrm{P}$, pregnenolone; E1, estrone; E2, $17 \beta$ estradiol; $3 \beta$-diol, $\alpha$-Androstane-3 $\beta, 17 \beta$-diol; THP, tetrahydro-progesterone.

number of other compounds (Figure 1) (Diotel et al., 2011a). Among the identified steroids figured 17hydroxy-pregnenolone, dehydroepiandrosterone (DHEA), androstenedione, testosterone, dihydro-testosterone (DHT), 17 $\beta$-estradiol (E2), estrone (E1), progesterone $(\mathrm{P})$, and dihydro-and tetrahydro-P (Figure 1). Based on these data, it is very likely that the brain of adult zebrafish exhibits at least the following biologically active enzymes: $3 \alpha$ HSD ( $3 \alpha$-hydroxysteroid dehydrogenase), 3 $\beta$-HSD, CYP17 (17 $\alpha-$ hydroxylase/17,20 lyase/17,20 desmolase), aromatase, 17 $\beta$-HSD, and $5 \alpha$-reductase (Diotel et al., 2011a). These data confirmed previous studies showing the existence of $3 \beta-\mathrm{HSD}$, aromatase, and $5 \alpha$-reductase activities in the brain of adult fish (Pasmanik and Callard, 1985; Sakamoto et al., 2001) and provided new information concerning steroidogenic enzyme activities. Figure 2 summarizes the active biosynthetic pathways of neurosteroid formation in the brain of adult zebrafish.

Confirming these data, a number of studies have demonstrated the expression of the main steroidogenic enzymes in the brain of fish, either in adults or in their developmental stages (Mathieu et al., 2001; Goto-Kazeto et al., 2004; Arukwe, 2005; Menuet et al., 2005; Lyssimachou and Arukwe, 2007; Tomy et al., 2007; Chen et al., 2010a; Diotel et al., 2010a,b, 2011a).

\section{EXPRESSION OF THE MAIN STEROIDOGENIC ENZYMES IN THE FISH BRAIN CYP11A1: CYTOCHROME P450 SIDE-CHAIN CLEAVAGE}

The cholesterol side-chain cleavage enzyme, P450scc, initiates the biosynthesis of all steroid hormones, by converting the 


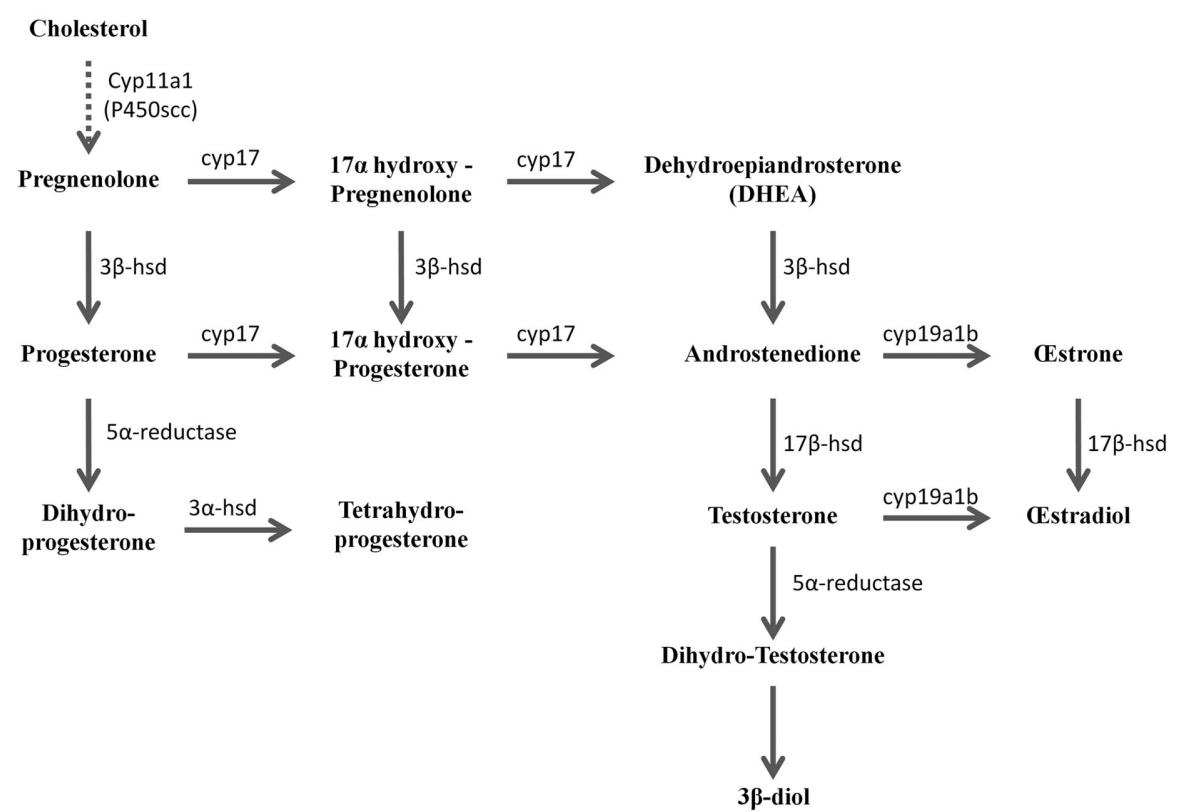

FIGURE 2 | Active biosynthetic pathways of neurosteroid formation in the brain of adult zebrafish (Reproduced from Diotel et al., 2011a with the kind permission of John Wiley \& Sons Ltd.). Cyp11a1 (P450scc), cytochrome P450 side-chain cleavage; Cyp17, cytochrome P450 17a-hydroxylase/C17, 20-lyase; Cyp19a1b, brain aromatase; 3 $\alpha-H S D$,
$3 \alpha$-hydroxysteroid dehydrogenase; $3 \beta$-HSD, 3 $\beta$-hydroxysteroid dehydrogenase D5-D4 isomerase; $3 \beta$-diol, $5 \alpha$-androstane- $3 \beta$, 17 $\beta$-diol; $5 \alpha$-R, $5 \alpha$-reductase; $17 \beta$-HSD, $17 \beta$-hydroxysteroid dehydrogenase. Full line arrows show active steroidogenic biosynthetic pathway in the brain of adult zebrafish. Dashed line arrow show undetermined steroidogenic biosynthetic pathway. precursor cholesterol into the $\mathrm{C}_{21}$-steroid, pregnenolone $\left(\Delta^{5} \mathrm{P}\right)$. The cytochrome P450scc is a mitochondrial enzyme encoded by the Cyp11a1 gene (Lieberman et al., 1984). It cleaves the C-20/C22-carbon/carbon, shortening the side chain of the precursor by six carbon atoms (Lieberman and Lin, 2001). The conversion of cholesterol into pregnenolone occurs in three monooxygenase reactions. Two hydroxylations of the cholesterol side chain take place, generating first 22R-hydroxycholesterol and $20 \alpha$, $22 \mathrm{R}$ dihydroxycholesterol. Finally, there is a cleavage between carbons 20 and 22, leading to the synthesis of pregnenolone and isocaproic acid.

In zebrafish, cyp11a1 transcripts were detected early during the development, notably in the yolk syncytial layer. In adults, cyp11a1 mRNAs were reported in the gonads, the interrenal glands, and the brain (Hsu et al., 2002; Hu et al., 2004). Real time-polymerase chain reaction (RT-PCR) and whole mount hybridization clearly showed that the cypllal transcripts were expressed in different parts of the zebrafish brain, such as the telencephalon, the preglomerular area, and the hypothalamus (Hsu et al., 2002). Nevertheless, whole mount hybridization did not allow identifying precisely the distribution of cyp11a1 mRNA. More recent investigations in zebrafish brain documented a wide expression of the cyp11a1 transcripts in the forebrain, spanning from the olfactory bulbs to more caudal parts of the brain such as the cerebellum. The cyp11a1 transcripts were notably detected in the subpallium, the anterior and mediobasal hypothalamus, or also in the optic tectum (Diotel et al., 2011a; Table 1; Figures 3 and 4). However, cyp11a1 gene expression appeared lower than that of other steroidogenic enzyme genes.

\section{P450 17 $\alpha$-HYDROXYLASE/C17,20 LYASE: P450C17 (CYP17)}

Cytochrome P450 17 $\alpha$-hydroxylase/c17,20 lyase $(\mathrm{P} 450 \mathrm{c} 17)$ is a microsomal enzyme involved in steroid synthesis. The $\mathrm{P} 450 \mathrm{c} 17$ enzyme is critical for steroidogenesis and exhibits two different activities, hydroxylase and lyase. Indeed, P450c17 catalyzes the hydroxylation of the $\mathrm{C}_{21}$ steroids (pregnenolone and progesterone) at carbon 17 of the steroid D ring (hydroxylase activity), but also acts upon 17-hydroxyprogesterone and 17hydroxypregnenolone, produced by the hydroxylase process, to split off the side chain from the steroid nucleus (the lyase activity; Miller et al., 1997).

Expression of $P 450 c 17$ was first documented in brain extracts of male and female fathead minnow (Pimephales promelas) by RTPCR and southern hybridization technique (Halm et al., 2003). The expression was about 30 times lower in the gonads than in the brain (Halm et al., 2003). Later, P450c17 expression was detected in the brain of different fish species, including the rice field eel (Yu et al., 2003), black porgy (Tomy et al., 2007, 2009), zebrafish (Wang and Ge, 2004; Diotel et al., 2011a), and rainbow trout (VizzianoCantonnet et al., 2011). In the tongue sole (Cynoglossus semilaevis), semiquantitative RT-PCR showed that cytochrome P450c17 was predominantly expressed in the ovaries and the brain (Chen et al., 2010a). In zebrafish, P450c17 gene expression was also reported in gonadal and extra-gonadal tissues (Wang and Ge, 2004). This study notably revealed that cyp17 gene expression is lower in females than in male zebrafish (Wang and Ge, 2004).

Until recently, the precise sites of cyp17 expression in the fish brain have not elucidated. Recent studies in zebrafish indicate that cyp17 mRNA is widely expressed in the brain in a way similar 
Table 1 | Distribution and relative abundance of cyp11a1, 3ß-hsd, cyp17, and cyp19a1b mRNAs in the brain of adult zebrafish.

\begin{tabular}{|c|c|c|c|c|}
\hline & cyp11a1 (P450scc) & $3 \beta-h s d$ & cyp17 & cyp19a1b Сур19a1b \\
\hline \multicolumn{5}{|l|}{ OLFACTORY BULBS } \\
\hline Internal cellular layer (ICL) & + & ++ & ++ & + \\
\hline External cellular layer (ECL) & + & ++ & ++ & - \\
\hline Glomerular layer (GL) & + & ++ & ++ & + \\
\hline \multicolumn{5}{|l|}{ SUBPALLIUM } \\
\hline Dorsal part (Vd) & $++/-$ & +++ & ++ & +++ \\
\hline Ventral part (Vv) & ++ & ++ & +++ & +++ \\
\hline \multicolumn{5}{|l|}{ PALLIUM } \\
\hline Central zone of D (Dc) & + & ++ & ++ & - \\
\hline Lateral zone of D (DI) & + & ++ & +++ & - \\
\hline Medial zone of D (Dm) & + & ++ & +++ & - \\
\hline Posterior zone of D (Dp) & $+/-$ & ++ & ++ & ++ \\
\hline \multicolumn{5}{|l|}{ AREA PREOPTICA } \\
\hline Anterior parvocellular preoptic nucleus (PPa) & ++ & +++ & ++ & ++++ \\
\hline Posterior parvocellular preoptic nucleus (PPp) & +++ & +++ & +++ & ++++ \\
\hline Suprachiasmatic nucleus (SC) & +++ & ++ & +++ & +++ \\
\hline Magnocellular preoptic nucleus (PM) & $++/-$ & + & ++ & ++ \\
\hline \multicolumn{5}{|l|}{ HYPOTHALAMUS } \\
\hline Ventral zone of the periventricular nucleus (Hv) & +++ & +++ & +++ & ++++ \\
\hline Anterior tuberal nucleus (ATN) & +++ & ++ & +++ & ++ \\
\hline Lateral hypothalamic nucleus (LH) & +++ & ++ & +++ & ++ \\
\hline Cells surrounding laterocaudal ventricular recesses (LR) & +++ & ++ & ++ & ++ \\
\hline Cells surrounding posterior ventricular recesses (PR) & ++ & ++ & +++ & ++++ \\
\hline Caudal zone of the periventricular hypothalamus $(\mathrm{Hc})$ & +++ & ++ & +++ & ++ \\
\hline Dorsal zone of periventricular hypothalamus $(\mathrm{Hd})$ & ++ & ++ & +++ & + \\
\hline Diffuse nucleus of the inferior lobe (DIL) & +++ & +++ & +++ & - \\
\hline Central nucleus of the inferior lobe (CIL) & ++ & ++ & +++ & - \\
\hline \multicolumn{5}{|l|}{ MESENCEPHALON } \\
\hline Tectum opticum (TeO) & +++ & +++ & +++ & $+/-$ \\
\hline Torus longitudinal (TL) & ++ & +++ & +++ & + \\
\hline Torus semicircularis (TS) & ++ & ++ & $++/-$ & + \\
\hline Cerebellum (VCe $+\mathrm{Ce})$ & +++ & +++ & +++ & $+1-$ \\
\hline
\end{tabular}

The following scale was used: +++, high density; ++, moderate density; +, low density; +/-, very low density; -, no mRNA expression; ND, not determined.

to what was described above for the cyp11a1 gene. Indeed, cyp17 mRNAs were detected in the olfactory bulbs, the ventral and dorsomedial telencephalon, the preoptic area, various nuclei in the hypothalamus, the optic tectum, and the cerebellum (Diotel et al., 2011a; Table 1; Figures 3 and 4).

\section{$\beta$-HYDROXYSTEROID DEHYDROGENASE/ $\Delta$-5-4 ISOMERASE}

The $3 \beta$-HSD protein is a key steroidogenic enzyme. Through oxidizing and isomerizing reactions, it mediates the synthesis of progesterone from pregnenolone, 17-hydroxyprogesterone from 17-hydroxypregnenolone, and also androstenedione from dehydroepiandrosterone (DHEA). While $3 \beta$-HSD received some attention in the brain and the pituitary gland of the sarcopterygian African lungfish (Protopterus annectens) there is virtually no information on Actinopterygians, with the exception of zebrafish. In the African lungfish, $3 \beta$-HSD-like immunoreactivity occurs in cell bodies and fibers in various brain areas, notably in the pallium, the thalamus, the hypothalamus, the tectum, and the periaqueductal gray (Mathieu et al., 2001). In the brain of adult zebrafish, $3 \beta$-HSD-like immunoreactivity was detected in the dorsal telencephalic areas, the central posterior thalamic nucleus, the preoptic nuclei, and the posterior tuberal nucleus (Sakamoto et al., 2001). This $3 \beta$-HSD-like immunoreactivity was observed in cells with neuron-like morphology and in fibers mainly running in the anterior part of the brain (Sakamoto et al., 2001). This distribution is in contrast with data obtained from in situ hybridization showing expression in the olfactory bulbs, the ventral and dorsomedial telencephalon, the preoptic area, various nuclei of the hypothalamus, the optic tectum, and cerebellum. It should be noted that, this distribution is very similar to that reported for other steroidogenic enzymes such as P450scc, cyp 17, 3 $\beta$-hsd, and aromatase (Figures 3 and 4).

Interestingly, the three steroidogenic enzymes exhibit a similar overall pattern in most of the brain regions, suggesting their potential expression in the same cells, or at least the existence of true neurosteroidogenic brain regions, such as the preoptic area, 


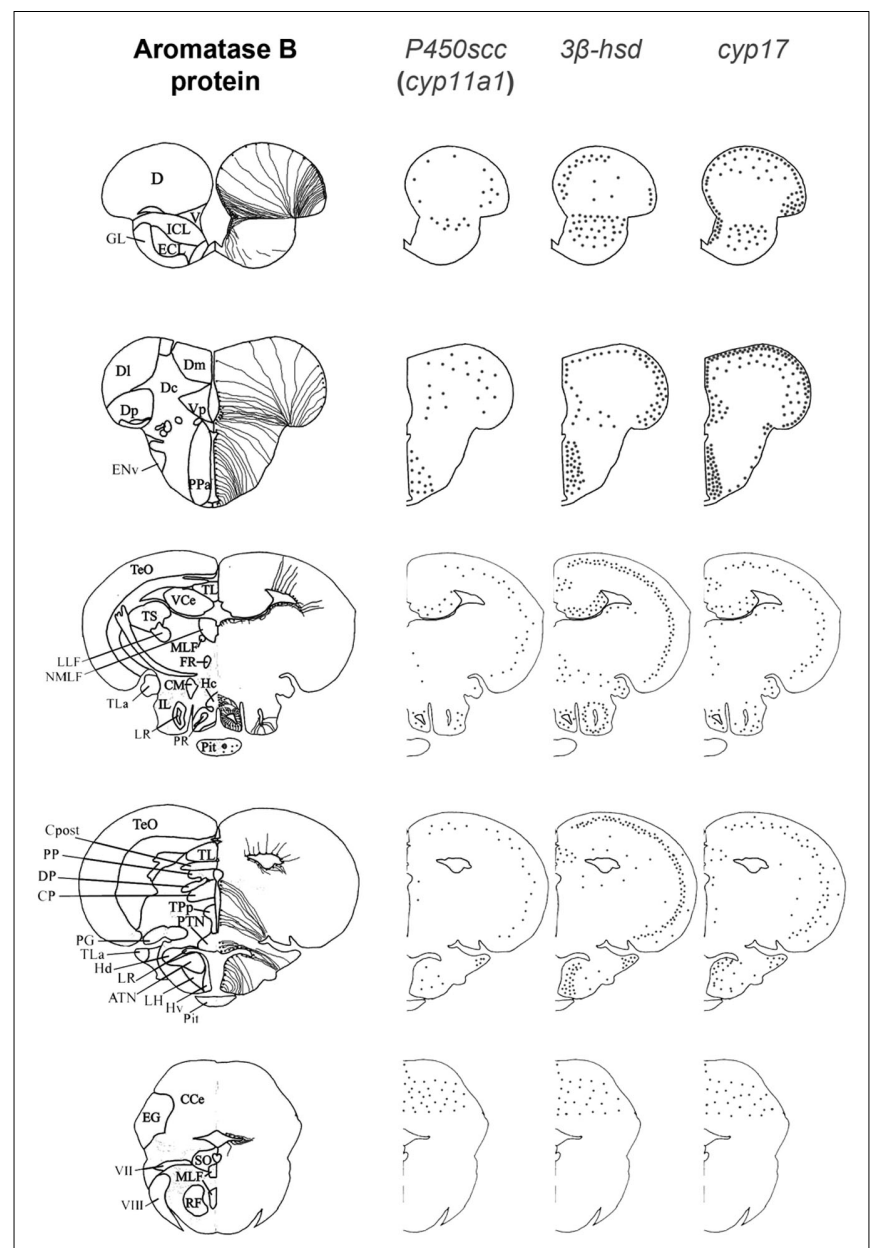

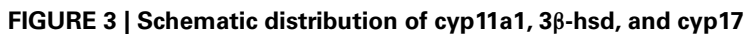
mRNA-expressing cells in representative sections taken from the zebrafish brain atlas (adapted from Wullimann et al., 1996). The cyp11a1, 33-hsd, and cyp 17 transcripts represented by black dots, exhibited a roughly similar distribution. Aromatase B-expressing cells are represented in the left panel (according to Menuet et al., 2005) where cell bodies are represented by dots, while thin lines figure radial processes.

the hypothalamus, and the cerebellum. Although the wide expression of $3 \beta$-hsd mRNA nicely matches with the distribution of $3 \beta$-HSD-immunoreactivity reported by Sakamoto et al. (2001), i.e., in the telencephalon, the preoptic area, the valvula cerebella, and the cerebellum, we also detected $3 \beta$-hsd transcripts in other regions, such as the hypothalamus and the optic tectum, and in neurons surrounding the lateral recess (Diotel et al., 2011a; Table 1; Figures 3 and 4 ).

\section{7 $\beta$-HYDROXYSTEROID DEHYDROGENASE: $17 \beta H S D$}

The $17 \beta-H S D$ proteins form a group of key enzymes involved in the last steps of steroid biosynthesis. These enzymes catalyze the conversion of 17-ketosteroids, such as D4 and estrone, and that of $17 \beta$-hydroxysteroids, such as testosterone and $17 \beta$-estradiol, by reduction, or oxidation at position $\mathrm{C} 17$ of the steroid backbone (Lin et al., 1997; Peltoketo et al., 1999; Adamski and Jakob, 2001; Do Rego et al., 2009). In fact, 17 $\beta$-HSD converts estrone into estradiol (and vice versa). Because 17 $\beta$-HSD type 3 exhibits the highest catalyzing activity is considered that is the main enzyme in the reduction of androstenedione into testosterone in mammalian and non-mammalian vertebrates, (Mindnich and Adamski, 2007). Interestingly, fish have nine types of $17 \beta-\mathrm{HSD}$ and only four of them (17 $\beta$-HSD type $1,2,3$, and 12$)$ have been characterized with respect to their catalytic activity and expression pattern (Mindnich et al., 2004, 2005, 2007; Mindnich and Adamski, 2007, 2009). In fish, the first $17 \beta-H S D$ (type 1 homolog) was cloned in the Japanese eel (Kazeto et al., 2000) and displays substrate specificity similar to its human homolog. Interestingly, in 1991, extra-gonadal $17 \beta$-hydroxysteroid dehydrogenase activity was found in the rainbow trout brain (Schulz and Blum, 1991). In zebrafish, 17ß-HSDs are not only expressed in steroidogenic organs linked to reproduction, namely testis and ovarian follicles (Mindnich et al., 2005; Ings and Van Der Kraak, 2006), but also, as RT-PCR experiments have demonstrated in the brain of both male and female zebrafish (Mindnich et al., 2004, 2005, 2007). However, the authors reported loss of $17 \beta$-HSD type 2 enzyme activity in zebrafish (Mindnich et al., 2007). Detailed studies on the precise sites of expression of $17 \beta-H S D$ in the fish brain are lacking.

\section{$5 \alpha$-REDUCTASE}

Also known as 3-oxo-5- $\alpha$-steroid 4-dehydrogenases, $5 \alpha$-reductase is a microsomal enzyme that reduces the $\mathrm{C} 4-\mathrm{C} 5$ double bond of several steroid substrates (Russell and Wilson, 1994; Do Rego et al., 2009). For example, $5 \alpha$-reductase leads to the conversion of testosterone into the more potent androgen $5 \alpha$-dihydro-testosterone (or also of progesterone into $5 \alpha$-dihydro-progesterone and 11-deoxycorticosterone into $5 \alpha$-dihydrodeoxycorticosterone (for review: Do Rego et al., 2009). It is also important to mention that aromatase and $5 \alpha$-reduction are required for the full expression of testosterone actions in neuroendocrine tissues. Very interestingly, the brain of teleost fish has been shown to exhibit a high $5 \alpha-$ reductase activity (Callard et al., 1978, 1980; Pasmanik and Callard, 1985). This intense $5 \alpha$-reductase activity was notably detected in goldfish and toadfish (Pasmanik and Callard, 1985, 1988; Pasmanik et al., 1988). We recently confirmed the existence of a high $5 \alpha$-reductase activity in the brain of adult zebrafish (Diotel et al., 2011a; Figure 1).

In teleost fish, $5 \alpha$-reductase activity was reported to be uniformly distributed throughout the brain. In addition, an increase was shown in brain $5 \alpha$-reductase activity when fish were reproductively inactive, which is in sharp contrast to aromatase (Pasmanik and Callard, 1988). Differing from aromatase activity that is upregulated by estradiol or testosterone treatments in reproductively inactive fish, $5 \alpha$-reductase activity was unaffected by steroid treatment in both reproductively active and inactive fish (Pasmanik et al., 1988).

\section{CYP19A1B/AROMATASE B: BRAIN AROMATASE}

Aromatase is part of a key enzymatic complex bound to the endoplasmic reticulum, which also includes the ubiquitous flavoprotein, NADPH cytochrome P450 reductase (Simpson and Davis, 2001; Diotel et al., 2010a). This enzymatic complex is the last of the steroidogenic synthetic pathway, and allows the conversion of aromatizable androgens into estrogens. In the teleost lineage, the 

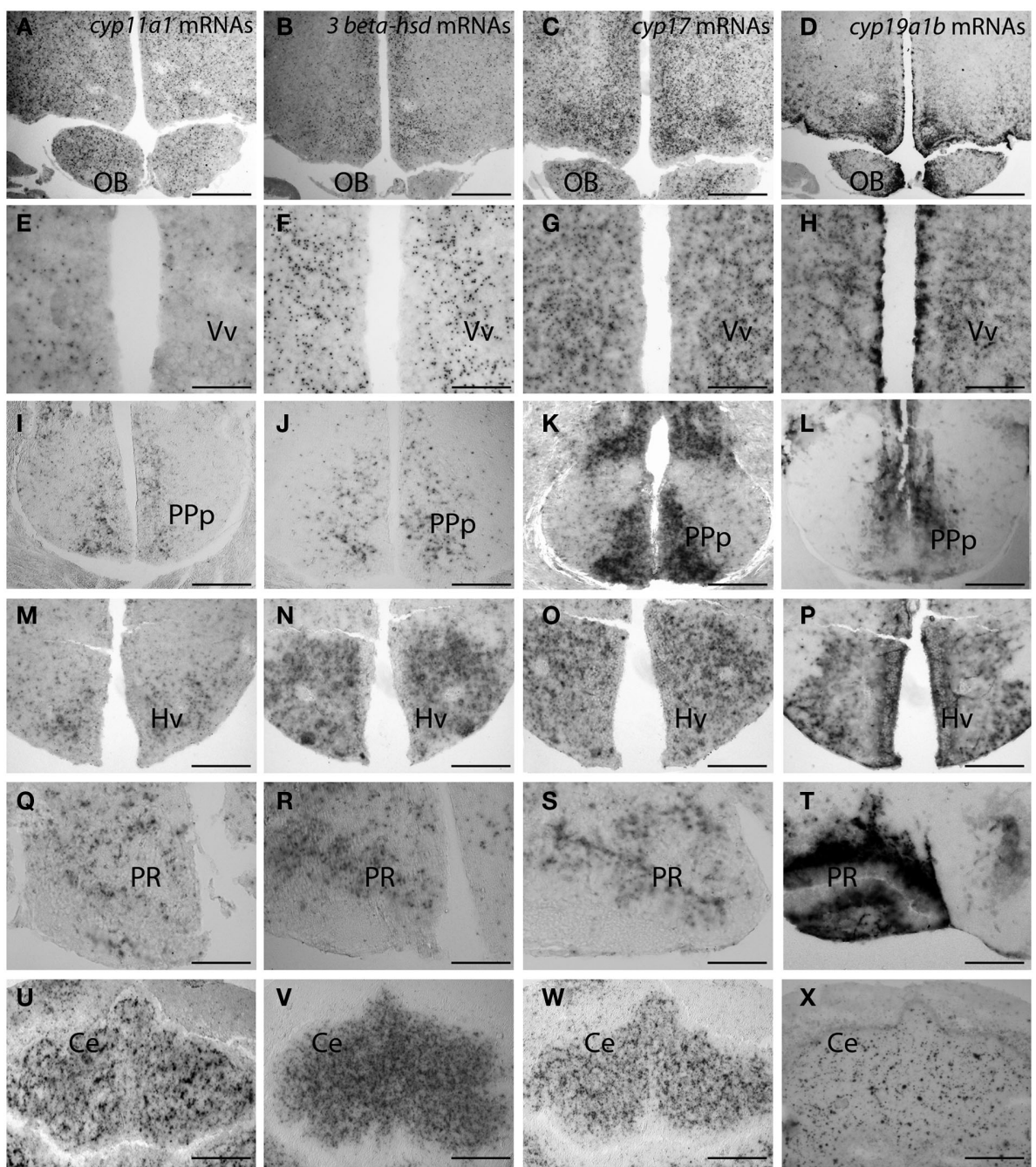

FIGURE 4 | Distribution of cyp11a1 (P450SCC), 3ß-hsd, and cyp17

transcripts in the brain of adult zebrafish. (Reproduced from Diotel et al.,

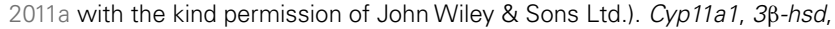
cyp17, and cyp19a1b mRNAs were detected with antisense probes at the junction between the olfactory bulbs and the telencephalon (A-D), in the ventral nucleus of the ventral telencephalic area $(\mathbf{E}-\mathbf{H})$, in the posterior part of the preoptic area (I-L), in the ventral zone of the periventricular hypothalamus
(M-P), in the nucleus of the recessus posterioris (Q-T), and in the cerebellum (U-X). Note that in (A-H) and (M-P), hybridization was performed on parallel sections of the same brain. $\mathrm{Ce}$, cerebellum; $\mathrm{Hv}$, ventral zone of the periventricular hypothalamus; OB, olfactory bulbs; PPp, posterior part of the preoptic area; $\mathrm{PR}$, posterior recess; $\mathrm{VV}$, ventral nucleus of the ventral telencephalic area. Scale bars: $80 \mu \mathrm{m}$ in $A, B, C, D, I, K, M, N, O$, and P; $40 \mu \mathrm{m}$ in $\mathrm{J}, \mathrm{L}, \mathrm{U}, \mathrm{V}, \mathrm{W}$, and $\mathrm{X} ; 20 \mu \mathrm{m}$ in $\mathrm{E}, \mathrm{F}, \mathrm{G}$, and $\mathrm{H}$.
3R whole genome duplication (Steinke et al., 2006) led to a large number of newly duplicated genes, among which cyp19a1 gene encoding aromatase. In most fish studied, two aromatase genes: the cyp19a1a gene, coding for aromatase A and mainly expressed in the gonads, and aromatase B, encoded by the cyp19a1b gene that is mainly expressed in the brain. Two such genes were identified in an increasing number of species including the rainbow trout (Tanaka et al., 1992; Valle et al., 2002), the zebrafish (Chiang et al., 2001; Kishida and Callard, 2001), the Nile tilapia (Kwon et al., 2001), the European sea bass (Blazquez and Piferrer, 2004, the protogynous wrasse, Halichoeres tenuispinis (Choi et al., 2005), the killifish (Greytak et al., 2005), the orange-spotted grouper Epinephelus coioides (Zhang et al., 2004), and the rice field eel, Monopterus albus (Zhang et al., 2008). However, until now, only one gene, more closely related to ovarian aromatase, has been reported in the Japanese eel (Ijiri et al., 2003).

In the fish brain, aromatase is the steroidogenic enzyme that has received most attention. Indeed, a wealth of information is available regarding aromatase activity, regulation, and expression in the brain (Pellegrini et al., 2005; Mouriec et al., 2008; Kah et al., 2009; Diotel et al., 2010a; Le Page et al., 2010). While pioneer studies as early as 1978 revealed that the brain of adult teleost fish exhibits strong aromatase activity (Callard et al., 1978, 1990; Pasmanik and Callard, 1985, 1988), it lasted till 2001 that Forlano et al. (2006) localized aromatase-expressing cells, using in situ hybridization and immunohistochemistry. They studied the brain of the plainfin midshipman (Porichthys notatus), a Batrachoidiform toadfish that is being intensively studied for its interesting 
sexual behavior. Aromatase transcripts were detected in the ventricular regions of the hindbrain, notably within the sonic motor nucleus, but also in the midbrain and in the forebrain (Forlano et al., 2001, 2006). Strikingly, aromatase expression was found to be restricted to a peculiar cell-type, the RGC, which was confirmed in several fish species (Menuet et al., 2003, 2005; Strobl-Mazzulla et al., 2008; Tong et al., 2009). Consistent with the localization of aromatase mRNAs, aromatase-positive cells exhibit small cell bodies localized along the brain ventricles and extending long cytoplasmic processes that reach the basal surface of the brain (Forlano et al., 2001, 2006). In addition, aromatase expression was closely related to that of GFAP (glial fibrillary acid protein, a well established marker of glial cells, best known for its expression in mammalian astrocytes (Forlano et al., 2001). Furthermore, aromatase-immunoreactive cells never exhibited neuronal markers such as $\mathrm{HuC/D}$ (Forlano et al., 2001).

The above data were confirmed by a similar study performed in the rainbow trout where, similarly, aromatase B transcripts were strongly detected in the periventricular layers of the anterior brain, in the tel-, di-, and mes-encephalon, in a way similar to the plain midshipman (Forlano et al., 2001). Main reproduction-related brain regions, viz. hypothalamus and preoptic area, strongly express aromatase transcripts. Strikingly, the pituitary gland and the saccus vasculosus also exhibit a strong hybridization signal (Menuet et al., 2003). Aromatase antisera from toadfish were successfully applied in rainbow trout (Menuet et al., 2003), in which aromatase-immunoreactive cells were detected in the three different lobes of the pituitary and in, possibly, ependymal, cells bordering the ventricles of the telencephalon and the ventral diencephalon, with a high expression in the preoptic area and the hypothalamus (Menuet et al., 2003). Aromatase-immunoreactive cells exhibit a small, ovoid nucleus, and are located along the ventricles, protruding a short end foot toward the ventricle and a long radial process ending near the pial surface (Menuet et al., 2003). Such positive cells were also observed in the torus semicircularis and in the optic tectum, where cell bodies were localized in the ependymal wall while their long processes crossed all tectal layers.

More recently, aromatase $\mathrm{B}$ and its mRNA were extensively studied in zebrafish (Goto-Kazeto et al., 2004; Pellegrini et al., 2005; Tong et al., 2009; Diotel et al., 2010a,b, 2011a; Le Page et al., 2010). The results clearly showed that aromatase B mRNA expression is similar to that reported in the plainfin midshipman and rainbow trout. Brain aromatase transcripts were found in the periventricular layers of the olfactory bulb, the ventral telencephalon, the preoptic area, the hypothalamus, and in the anterior and posterior lobes of the pituitary. Interestingly, in the zebrafish brain, the hybridization signal was distributed not only along the ventricular layer, but also within the parenchyma, far away from the nucleus of the radial cells (Menuet et al., 2005; Diotel et al., 2010a,b). With specific zebrafish aromatase B antisera (Menuet et al., 2005; Pellegrini et al., 2005) the distribution of aromatase B immunoreactive cells was shown to perfectly match in situ hybridization data, thereby confirming that aromatase $\mathrm{B}$ expression is restricted to RGC (Menuet et al., 2003; Pellegrini et al., 2005, 2007; Mouriec et al., 2008; Kah et al., 2009; Diotel et al., 2010a,b; Le Page et al., 2010; März et al., 2010) This expression is mainly observed in the olfactory bulbs, the telencephalon, the preoptic area, and the hypothalamus. However, positive cells were also detected in the optic tectum, the torus semicircularis, and around the fourth ventricle (Table 1; Figure 3).

\section{STEROID TARGETS IN THE BRAIN OF FISH}

The data mentioned above clearly indicate that not only peripheral steroids, but also neurosteroids, affect brain functions. Below, we will deal with the existing knowledge regarding expression in the teleost brain of "classical" nuclear steroid receptors for progesterone, androgens, and estrogen (see also Figure 5).

\section{PROGESTERONE RECEPTORS}

Information documenting the expression of progesterone receptors (Pgr), either nuclear or membrane-bound, in the brain of fish is scarce. In zebrafish, a single nuclear Pgr locus and a unique full-length $p g r$ transcript were characterized (Chen et al., 2010b; Hanna et al., 2010). Nuclear Pgr binding assays and dual transactivation/transcription assays clearly established that progestins, including progesterone, 17-hydroxyprogesterone, dihydroprogesterone, and 4-pregnen-17,20 $\beta$-diol-3-one (17,20- $\beta$-DHP) actively and specifically bind and activate zebrafish Pgr (Chen et al., 2010b; Hanna et al., 2010). According to data in zebrafish, Pgr are strongly expressed and exhibit a very large distribution within the brain, suggesting that the central actions of progestagens in fish probably extend beyond reproductive functions, possibly including neurogenesis, neuronal plasticity, and/or neuroprotection. Figure 5 shows the wide distribution of Pgr in neuroendocrine but also in non-neuroendocrine regions of the brain. Furthermore, Pgr seem to be expressed not only by neurons but also by cells lining the ventricle, suggesting a possible expression in RGC (Hanna et al., 2010). A widespread expression of Pgr was also documented in an African cichlid, Astatotilapia burtoni, in similar reproductive and non-reproductive regions (Munchrath and Hofmann, 2010). In this species, the Pgr and its mRNA are distributed throughout the telencephalon and diencephalon, and in some mesencephalic structures. The authors show that Pgr are especially located in key brain regions known to modulate social behavior in other vertebrates, including the proposed teleost homologs of the mammalian amygdala complex, the hippocampus, the preoptic area, and the hypothalamus, and could modulate such social and sexual behavior (Munchrath and Hofmann, 2010).

Our recent data on Pgr expression in zebrafish clearly show that Pgr are expressed both neurons and RGC (Diotel et al., 2011b). Staining sections of transgenic fish expressing green fluorescent protein (GFP) in RGC (cyp19a1b:GFP) clearly demonstrated strong staining of such glial cells. Interestingly, Pgr expression was stronger in aromatase B RGC than in neurons. Such an observation suggests that RGC, which are neural stem cells in the brain of adult zebrafish, could represent special targets for progestagen signaling. Progestagens could indeed modulate the activity of RGC, by modifying either their proliferative activity or the fate of the newborn cells. By performing qPCR experiments, we demonstrated that estrogen treatment led to a significant increase in Pgr expression, whereas blocking aromatase activity, and thus reducing estrogen availability, caused a significant decrease of this expression (Diotel et al., 2011b). Altogether these data show that Pgr are widely expressed in the teleost brain and regulated by the 

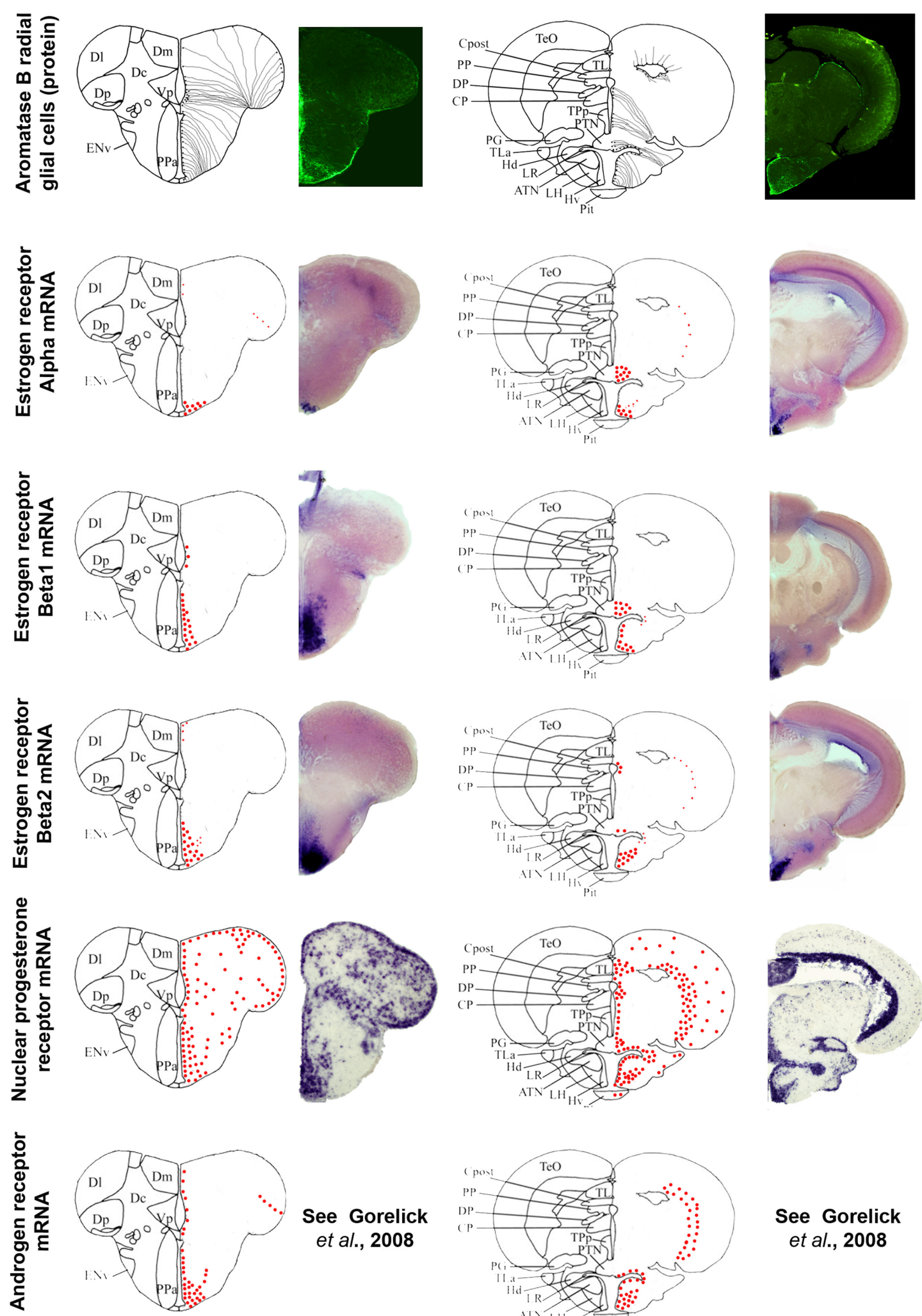

FIGURE 5 | Aromatase and estrogen, progesterone, and androgen receptors expression in the brain of adult zebrafish. The estrogen, progesterone, and androgen receptors are represented by red dots in brain sections taken from the zebrafish brain atlas (adapted from Wullimann et al.

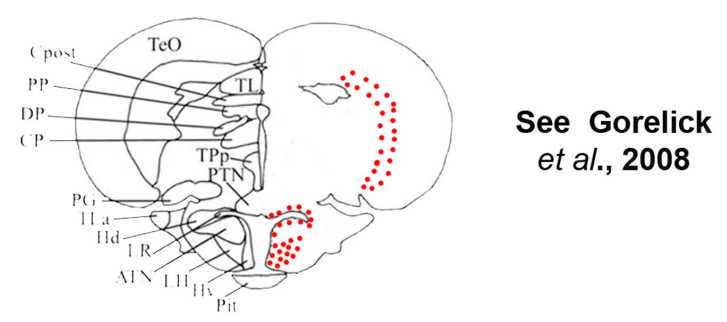

1996). Data on androgen receptors are adapted from Gorelick et al. (2008). Aromatase B-expressing cells are represented in the left panel (according to Menuet et al., 2005) where cell bodies are represented by black dots, while thin lines figure radial processes. 
estrogenic environment. Furthermore, the stronger expression of Pgr in estrogen-synthesizing RGC (Diotel et al., 2011b), suggests a key role of steroids and a probably local action of neurosteroids on RGC activity.

\section{ANDROGEN RECEPTORS}

In teleost fish, the number of androgen receptors (AR for the protein and ar for the gene) varies according to species. While two potential sequences were cloned in rainbow trout and Atlantic croaker (Sperry and Thomas, 1999; Takeo and Yamashita, 1999; Smolinsky et al., 2010), one of the trout sequences encoded a nonfunctional protein. In zebrafish, only one sequence was retrieved, which binds $5 \alpha$-dihydro-testosterone, 11-ketotestosterone, testosterone, and androstenedione (Jorgensen et al., 2007; De Waal et al., 2008; Smolinsky et al., 2010). This is consistent with the hypothesis that three different events are responsible for the observed diversity of ARs in Actinopterygians: an early whole genome duplication, a parallel loss of one duplicate in several lineages, and a putative neofunctionalization of the same duplicate in modern fish (Douard et al., 2008).

There is only limited data on the distribution of androgen receptor mRNA or protein in the brain of fish. In the electric fish (Brachyhypopomus gauderio) AR-immunoreactive cells were detected in different regions of the brain, mainly in the forebrain in the telencephalon, the preoptic area, and the hypothalamus, but also in the hindbrain (Pouso et al., 2010). In this study, the authors also observed AR-positive cells that possibly contact the cerebrospinal fluid. Consequently, such liquor-contacting cells are RGC, whose somata are located along the ventricle. By performing in situ hybridization, androgen receptor mRNA expression was found throughout the central nervous system of the plainfin midshipman fish (Porichthys notatus; Forlano et al., 2010). The ar transcripts were abundantly detected in the forebrain, the parvocellular and magnocellular nuclei of the preoptic area, the nucleus preglomerulosus, and the posterior, the ventral, and the anterior tuberal nuclei of the hypothalamus (Forlano et al., 2010). In this species many of these nuclei are part of the known vocal and auditory circuitry. Indeed, ar expression has not only been demonstrated in the midbrain periaqueductal gray but in the inner ear (Forlano et al., 2010). Therefore, this particular AR distribution suggests a role of androgens as modulators of behaviorally defined vocal, auditory, and neuroendocrine circuits (Forlano et al., 2010).

In zebrafish, in situ hybridization of androgen receptor mRNA has been performed in the developing and adult brain (Gorelick et al., 2008). Androgen receptor transcript were detected in numerous (neuroendocrine) regions, such as the preoptic area, the ventricular and periventricular layers of the anterior, mediobasal, and caudal hypothalamus, and the periglomerular gray zone of the optic tectum (Gorelick et al., 2008). Interestingly, this distribution neatly matches that of aromatase B and estrogen receptor (ER for the protein and es $r$ for the gene) mRNA (see below and Figure 5), suggesting tight links between $\mathrm{AR}, \mathrm{ER}$, and aromatase $\mathrm{B}$ expressed in RGC.

\section{ESTROGEN RECEPTORS}

In fish, three distinct zfER have been cloned and characterized: $\mathrm{ER} \alpha, \mathrm{ER} \beta 1$, and $\mathrm{ER} \beta 2$, corresponding to esr 1 , esr $2 b$, and esr $2 a$, respectively. In zebrafish, estradiol binding assays with the three different ER isoforms expressed in rabbit reticulocyte lysate showed that estradiol specifically binds ER, with a dissociation constant ranging from 0.4 (zfER $\beta 2)$ to $0.75 \mathrm{nM}(\mathrm{zfER} \alpha$ and zfER $\beta 2$ ). In situ hybridization experiments clearly revealed a strong expression of each isoform in the anterior and posterior preoptic area, and in the hypothalamus (Menuet et al., 2002). The fact that the estrogen receptors mRNAs exhibit (Oakley et al., 2009) roles of each zfER in estradiol signaling in these neuroendocrine regions (Menuet et al., 2002). Antisera to fish ER have only been raised in rainbow trout and only for ER $\alpha$ (Anglade et al., 1994; Pakdel et al., 1994), showing a strong expression in the ventral telencephalon, the preoptic area, and the mediobasal hypothalamus. Comparing aromatase and esr $1(\mathrm{ER} \alpha)$ expression established that a strong aromatase signal occurs in regions expressing esr 1 , such as the preoptic area and the hypothalamus (Menuet et al., 2003). Brain cell cultures indicated that glial cells express ER $\alpha$ (Menuet et al., 2003). In zebrafish, the estrogen receptor isoforms $\beta 1$ and $\beta 2$ are expressed along the brain ventricles in the telencephalon, the preoptic area, and the hypothalamus (Figure 5). Although this suggests that zfER is present in RGC, no double stainings were performed to provide evidence for estrogen receptor expression in aromatase B RGC. Given the fact that in vitro and in vivo experiments clearly established that aromatase $\mathrm{B}$ expression is up-regulated by estrogens (Le Page et al., 2006, 2010; Cheshenko et al., 2007; Diotel et al., 2010a), it is likely that estrogen receptors are expressed at very low levels in RGC but sufficiently high to up-regulate aromatase expression. In rainbow trout, $\mathrm{ER} \alpha$ is consistently expressed in the dopaminergic neurons of the anteroventral preoptic region that are responsible for the inhibition of $\mathrm{LH}$ release during vitellogenesis (Linard et al., 1996). On the other hand, in trout, salmon GnRH does not express ER $\alpha$ (Navas et al., 1995). It is likely, that similar to mammals, estrogen feedback on $\mathrm{GnRH}$ neuron activity is mediated by kisspeptin-producing neurons. Kisspeptins have recently emerged as key players in the neuroendocrine control of reproduction in mammals (Oakley et al., 2009). Recent data in zebrafish and European sea bass have demonstrated that kiss neurons in the mediobasal hypothalamus are targets for estrogens (Servili et al., 2011).

Recent data document the expression of the plasma membraneassociated estrogen receptor, GPR30, in the brain of adult fish (Liu et al., 2009). However, the precise sites of expression have not been established yet. In the brain of the orange-spotted grouper (Epinephelus coioides), GPR30 but not nuclear androgen receptor, revealed a significant increase at 110 days post hatching in the forebrain and midbrain during gonadal sex differentiation (Nagarajan et al., 2011).

\section{RADIAL GLIAL CELLS: A POTENTIAL SOURCE AND TARGET OF NEUROSTEROIDS?}

In mammals (Zwain and Yen, 1999; Sinchak et al., 2003; Lavaque et al., 2006; Do Rego et al., 2009) and other vertebrates such as amphibians (Do Rego et al., 2009; Bruzzone et al., 2010) and birds (Schlinger et al., 1994), steroidogenic enzymes are expressed in both neurons and astrocytes. In teleosts, there is accumulating evidence to suggest that typical astrocytes are lacking. This is not surprising as RGC, from which mammalian astrocytes are 
derived, persist throughout adulthood (Menuet et al., 2005; Pellegrini et al., 2007; Diotel et al., 2010a; März et al., 2010), at least in the forebrain. Therefore, the possibility exists that RGC retain some ancestral functions of astrocytes, in particular the capacity to produce neurosteroids.

\section{RADIAL GLIAL CELLS EXPRESS THE TRANSCRIPTS OF THE MAIN STEROIDOGENIC ENZYMES}

Based on immunohistochemistry using an aromatase B antiserum and $\operatorname{tg}(c y p 19 a 1 b-G F P)$ transgenic fish that expresses GFP under the control of the cyp19a1b promoter, there is no doubt that aromatase B is expressed in RGC and only in such cells. This conclusion is reinforced by the fact that aromatase $\mathrm{B}$ is co-expressed with well-characterized markers of RGC such as brain lipid-binding protein, GFAP, and nestin (Diotel et al., 2010a; März et al., 2010). Thus, all these studies point to RGC as the unique site of aromatase $\mathrm{B}$ expression. However, surprisingly, in contrast to what has been observed in the brains of the rainbow trout and the plain fin midshipman (Forlano et al., 2001; Menuet et al., 2003), the cyp19a1b mRNA in the brain of zebrafish has also been detected in high amounts in the RGC processes and their end feet (Pellegrini et al., 2005; Diotel et al., 2010a,b, 2011a). In fact, there is a virtually perfect overlap between the distribution of aromatase $\mathrm{B}$ and that of the corresponding mRNA in RGC (Menuet et al., 2005; Pellegrini et al., 2007; Kah et al., 2009; Tong et al., 2009; Diotel et al., 2010a,b; März et al., 2010). This is further supported by the fact that performing aromatase B immunohistochemistry after cyp19a1b in situ hybridization clearly showed that cyp19a1b mRNAs, detected in the brain parenchyma remote from the ventricular layer, were localized inside the RGC processes and accumulated in the end feet of RGC at the periphery of the brain (Diotel et al., 2010b, 2011a). These data demonstrate that cyp19a1b mRNAs are transported inside RGC processes (Menuet et al., 2005; Pellegrini et al., 2005; Kah et al., 2009; Diotel et al., 2010a,b).

As previously mentioned, cyp11a1, $3 \beta-h s d, c y p 17$, and $c y p 19 a 1 b$ transcripts are widely expressed in the forebrain, such as at the junction between the olfactory bulbs and the dorsal telencephalon, in the pallial and subpallial regions, and in the dorsomedial and dorsolateral telencephalon (Diotel et al., 2011a). These transcripts are also present in the preoptic area and the mediobasal hypothalamus. In addition, an in situ hybridization signal was observed in the nuclei surrounding the lateral and posterior recesses, in the optic tectum, in the valvula, and in the corpus cerebellum. As appeared from observations on parallel sections (Figure 4), in most of these regions the overall expression patterns of the cyp11a1, $3 \beta-h s d, c y p 17$, and cyp19a1b genes are very similar.

In contrast to the strong cyp19a1b staining, the hybridization signals generated by the other probes are much lower and consistently appear as small dots that do not necessarily corresponds to cell somata as shown by nuclear DAPI staining. Thus, cyp11a1, $3 \beta$-hsd, and cyp17 mRNAs can occur at sites remote from cell somata, in a way similar to what has been described for cyp19a1b mRNAs (Diotel et al., 2011a). Consequently, it is likely that part of these mRNAs could, similar to cyp19a1b mRNAs, be exported in processes of RGC. The existence of such mRNA in neuronal and/or glial processes is well established nowadays (Martin and Zukin, 2006; Lin and Holt, 2008; Raju et al., 2008). In mammals, transcripts can be found to form "mRNA granules," sometimes considered as remnants of an "ancient RNA world." Such granules contain independent translational units, capable of moving within the cytoplasm and allowing delivery of mRNAs at specific sites of the cell for later activation. These RNA granules could thus exert a post-transcriptional control over gene expression (Anderson and Kedersha, 2009) and play a role in plasticity and regulation (Martin and Zukin, 2006; Lin and Holt, 2008; Raju et al., 2008).

Aromatase B immunohistochemistry following cyp11a1, $3 \beta$ hsd, and cyp17 fluorescent in situ hybridization, has shown that at least part of these mRNAs occur in RGC somata and/or in their processes (Diotel et al., 2011a). Consequently, RGC could express the whole series of steroidogenic enzymes and thus be genuine steroidogenic cells. Such data are particularly relevant given the fact that RGC are well established as progenitors cells in the adult fish brain. Indeed, RGC are neural "stem cells" that support to a high degree the active neurogenic activity observed in adults (Pellegrini et al., 2007; Kah et al., 2009; Diotel et al., 2010a; März et al., 2010).

\section{RADIAL GLIAL CELLS ARE TARGETS FOR STEROIDS}

It is now well documented that the cyp19a1b gene is up-regulated by estrogens only in RGC, indicating strong cell specificity (Menuet et al., 2005; Pellegrini et al., 2005; Le Page et al., 2008, 2010; Mouriec et al., 2008; Diotel et al., 2010a). In vitro studies have shown that E2 up-regulation of a cyp19a1b-luciferase reporter gene in the presence of ER can be achieved only in some cell types such as in the human astrocyte cell line U-251MG. Integrity of the estrogen-responsive element (ERE) located at $-348 \mathrm{bp}$ of the cyp19a1b promoter is a prerequisite for this estrogenic regulation (Menuet et al., 2005; Le Page et al., 2008). However, a short sequence of $20 \mathrm{bp}$ called GxRE and located upstream the ERE, appears as an important actor of the cell specificity and regulation by estrogens derived from cyp19a1b (Le Page et al., 2008). This GxRE motif seems to act as an autonomous cis element, by increasing the estrogenic up-regulation of cyp19a1b, exclusively in the glial cell context (Le Page et al., 2008). When comparing the distribution of steroid receptors with that of aromatase B (Figure 5), it is clear that overlap exists, suggesting the expression of steroid receptors in RGC, especially in neuroendocrine regions. Indeed, estrogen receptors $\beta 1$ and $\beta 2$ transcripts are present in the ventricular layers in the subpallial and pallial regions, the preoptic area, and the mediobasal hypothalamus (Figure 5). Thus, the current assumption is that estrogen receptors are probably expressed at low levels in RGC, but sufficiently high to induce cyp19a1b, due to the gene's high sensitivity to estrogens. More recently, it was shown that the nuclear Pgr is induced by estrogens in RGC of zebrafish (Diotel et al., 2011b).

Similarly, androgen receptors exhibit an overall pattern similar to that of ER $\beta$ in many regions. According (Gorelick et al., 2008), androgen receptors transcripts are detected in the ventricular layer in RGC. These data suggest that part of the ar mRNA is expressed in such cells. The molecular targets of potential androgen receptor in the RGC remain to be established.

Finally, Pgr were recently shown to be widely expressed in the brain of zebrafish, in particular in aromatase B RGC (Hanna et al., 
2010). Consequently, it appears that RGC, at least part of them, express nuclear estrogen receptors, androgen, and Pgr.

\section{EXPRESSION OF STEROIDOGENIC ENZYMES DURING DEVELOPMENT}

There are limited data regarding the early expression of steroidogenic enzymes in the brain of fish. In fact, detailed information is only available for cyp19a1b which expression increases progressively during development. In particular, there is a significant increase between $24 \mathrm{~h}$ post fertilization (hfp) and $48 \mathrm{hpf}$, which seems to be linked to a simultaneously increasing ER expression (Mouriec et al., 2008, 2009b). This basal expression of aromatase $\mathrm{B}$ is thought to be ER-mediated, because it can be blocked by specific estrogen antagonists (Mouriec et al., 2009b). In rainbow trout, Vizziano-Cantonnet et al. (2011) demonstrated expression

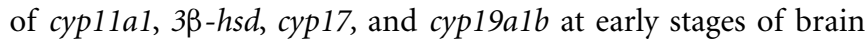
development. Interestingly, using genetic monosex populations, it was shown that $c y p 11 a 1,3 \beta-h s d$, and $c y p 19 a 1 b$ mRNA levels, but not those of cyp17, were higher in males than in females over the period of gonadal sex differentiation (35 to 63 days post-fecundation), suggesting a function of neurosteroids in brain sexual differentiation. Furthermore, mRNA levels of the three ER genes, esr 1, esr2a, and esr2b, were also much higher in males than in females (Vizziano-Cantonnet et al., 2011). In the same line, Tomy et al. (2007) have suggested that the brain of black porgy (Acanthopagrus schlegeli), a protandrous hermaphrodite fish, has the capacity to produce neurosteroids that might be important for sex changes in the brain.

\section{CONCLUSION AND PERSPECTIVES}

Similar to that of mammals, amphibians, and birds, the brain of teleost fishes emerges as a steroidogenic organ. Thirty years after the pioneer studies documenting elevated aromatase and $5 \alpha$-reductase activities in the brain of different species (Callard et al., 1978), it seems established that a wide variety of neurosteroids can be produced from cholesterol. In comparison with other vertebrates, the remarkable feature of teleost fishes lies in the fact that the steroidogenic enzymes seem to be preferentially expressed within RGC. While this is very clear in the case of aromatase, this assumption needs to be reinforced in the case of other

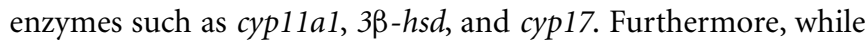
it is known that $5 \alpha$-reductase is very active in fish brain, nothing is known on its sites of expression. Experiments in progress should identify where $5 \alpha$-reductase mRNA and protein are expressed. Indeed, there is good evidence in zebrafish that the brain can convert testosterone or dihydrotestosterone into $5 \alpha$-androstane3beta, 17beta-diol (betadiol), and that this androgenic compound

\section{REFERENCES}

Adamski, J., and Jakob, F. J. (2001). A guide to 17beta-hydroxysteroid dehydrogenases. Mol. Cell. Endocrinol. 171, 1-4.

Adolf, B., Chapouton, P., Lam, C. S., Topp, S., Tannhauser, B., Strahle, U., Gotz, M., and Bally-Cuif, L. (2006). Conserved and acquired features of adult neurogenesis in the zebrafish telencephalon. Dev. Biol. 295, 278-293.

Andersson, E., Borg, B., and Lambert, J. G. (1988). Aromatase activity in brain and pituitary of immature and mature Atlantic salmon (Salmo salar L.) parr. Gen. Comp. Endocrinol. 72, 394-401.

can efficiently activate zebrafish ER (Mouriec et al., 2009a) similar to what was already evidenced in mammals.

We hypothesize that such locally produced steroids act in a way similar to what has been described for sex steroids in mammals or fish, acting especially on reproduction, sexual behavior, neurogenesis, brain plasticity, and regeneration (Do Rego et al., 2009). A key issue will be to examine how all these enzyme expressions and activities are regulated. In amphibians, recent data suggest that classical neurotransmitters as well as neuropeptides finely regulate neurosteroid biosynthesis (Do-Rego et al., 2006; Do Rego et al., 2009) and this important aspect needs to be examined in fish as well.

In the brain of adult zebrafish, the main steroidogenic enzymes

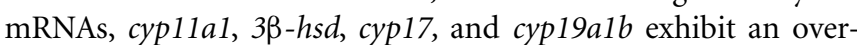
all similar pattern, particularly in neuroendocrine brain regions. Furthermore, parts of the cyp11a1, $3 \beta$-hsd, and cyp17 transcripts are expressed in aromatase B-containing RGC. These data suggest that RGC are true steroidogenic cells in addition of being neurogenic (Pellegrini et al., 2007; Diotel et al., 2010b; StroblMazzulla et al., 2010). This fact is particularly interesting given the fact that the whole steroidogenic chain is expressed in neurogenic regions, such as the ventral telencephalon, the preoptic area, the hypothalamus, and the cerebellum (Diotel et al., 2011a), and that RGC are neural progenitors (Adolf et al., 2006; Chapouton et al., 2007; Pellegrini et al., 2007; Kah et al., 2009; Lam et al., 2009; Diotel et al., 2010a; März et al., 2010). Because radial glial stem cells appear to be targeted by steroids (i.e., by estrogens, progestagens and, possibly, by androgens) and in view of our recent demonstration that a steroidogenic environment modulates brain neurogenesis in adults (Diotel et al., unpublished), it is likely that one of the functions of these neuroactive steroids is to modulate this neurogenic process. In mammals, "neurosteroidogenesis" occurs in regions of the brain implicated in learning, such as the hippocampus. This suggests key roles of neurosteroids in cognitive brain functions (Baulieu, 1997; Tsutsui and Ukena, 1999; Tsutsui et al., 1999; Compagnone and Mellon, 2000; Mellon et al., 2001; Do Rego et al., 2009). Similarly, it could be possible that locally produced steroids in fish act at synaptic and dendritic spine plasticity in order to modulate behavior and/or also brain sex changes, which is a unique feature of teleost fish among vertebrates (Le Page et al., 2010). However, the underlying mechanisms are far from being deciphered and may require years of exciting but promising research.

\section{ACKNOWLEDGMENTS}

Grants: funded by the European project n222719 (LIFECYCLE to Olivier Kah) and the ANR NEED (CES 2008-011).

Anderson, P., and Kedersha, N. (2009). RNA granules: post-transcriptional and epigenetic modulators of gene expression. Nat. Rev. Mol. Cell Biol. 10, 430-436.

Anglade, I., Pakdel, F., Bailhache, T., Petit, F., Salbert, G., Jego, P., Valotaire, Y., and Kah, O. (1994). Distribution of estrogen receptor-immunoreactive cells in the brain of the rainbow trout (Oncorhynchus mykiss). J. Neuroendocrinol. 6, 573-583.

Arukwe, A. (2005).Modulation of brain steroidogenesis by affecting transcriptional changes of steroidogenic acute regulatory (StAR) protein and cholesterol side chain 
cleavage (P450scc) in juvenile Atlantic salmon (Salmo salar) is a novel aspect of nonylphenol toxicity. Environ. Sci. Technol. 39, 9791-9798.

Baulieu, E. E. (1997). Neurosteroids: of the nervous system, by the nervous system, for the nervous system. Recent Prog. Horm. Res. 52, 1-32.

Blazquez, M., and Piferrer, F. (2004). Cloning, sequence analysis, tissue distribution, and sex-specific expression of the neural form of P450 aromatase in juvenile sea bass (Dicentrarchus labrax). Mol. Cell. Endocrinol. 219, 83-94.

Borg, B., Timmers, R. J., and Lambert, J. G. (1987a). Aromatase activity in the brain of the three-spined stickleback, Gasterosteus aculeatus. I. Distribution and effects of season and photoperiod. Exp. Biol. 47, 63-68.

Borg, B., Timmers, R. J., and Lambert, J. G. (1987b). Aromatase activity in the brain of the three-spined stickleback, Gasterosteus aculeatus. II. Effects of castration in winter. Exp. Biol. 47, 69-71.

Bruzzone, F., Do Rego, J. L., Luuthe, V., Pelletier, G., Vallarino, M., and Vaudry, H. (2010). Immunohistochemical localization and biological activity of 3betahydroxysteroid dehydrogenase and 5 alpha-reductase in the brain of the frog, Rana esculenta, during development. J. Chem. Neuroanat. $39,35-50$.

Callard, G., Schlinger, B., Pasmanik, M., and Corina, K. (1990). Aromatization and estrogen action in brain. Prog. Clin. Biol. Res. 342, 105-111.

Callard, G. V., Petro, Z., and Ryan, K. J. (1978). Phylogenetic distribution of aromatase and other androgenconverting enzymes in the central nervous system. Endocrinology 103, 2283-2290.

Callard, G. V., Petro, Z., and Ryan, K. J. (1980). Aromatization and 5 alphareduction in brain and nonneural tissues of a cyclostome, Petromyzon marinus. Gen. Comp. Endocrinol. 42, 155-159.

Chapouton, P., Jagasia, R., and BallyCuif, L. (2007). Adult neurogenesis in non-mammalian vertebrates. Bioessays 29, 745-757.

Chen, C. F., Wen, H. S., Wang, Z. P., He, F., Zhang, J. R., Chen, X. Y., Jin, G. X., Shi, B., Shi, D., Yang, Y. P., Li, J. F., Qi, B. X., and Li, N. (2010a). Cloning and expression of $\mathrm{P} 450 \mathrm{c} 17$ I (17alpha-hydroxylase/17,20-lyase) in brain and ovary during gonad development in Cynoglossus semilaevis. Fish Physiol. Biochem. 36, 1001-1012.

Chen, S. X., Bogerd, J., Garcia-Lopez, A., De Jonge, H., De Waal, P. P., Hong, W. S., and Schulz, R. W. (2010b). Molecular cloning and functional characterization of a zebrafish nuclear progesterone receptor. Biol. Reprod. 82, 171-181.

Cheshenko, K., Brion, F., Le Page, Y., Hinfray, N., Pakdel, F., Kah, O., Segner, H., and Eggen, R. I. (2007). Expression of zebra fish aromatase cyp19a and cyp19b genes in response to the ligands of estrogen receptor and aryl hydrocarbon receptor. Toxicol. Sci. 96, 255-267.

Chiang, E. F., Yan, Y. L., Guiguen, Y., Postlethwait, J., and Chung, B. (2001). Two Cyp19 (P450 aromatase) genes on duplicated zebrafish chromosomes are expressed in ovary or brain. Mol. Biol. Evol. 18, 542-550.

Choi, J. Y., Park, J. G., Jeong, H. B., Lee, Y. D., Takemura, A., and Kim, S. J. (2005). Molecular cloning of cytochrome P450 aromatases in the protogynous wrasse, Halichoeres tenuispinis. Comp. Biochem. Physiol. B Biochem. Mol. Biol. 141, 49-59.

Compagnone, N. A., and Mellon, S. H. (2000). Neurosteroids: biosynthesis and function of these novel neuromodulators. Front. Neuroendocrinol. 21, 1-56.

De Waal, P. P., Wang, D. S., Nijenhuis, W. A., Schulz, R. W., and Bogerd, J. (2008). Functional characterization and expression analysis of the androgen receptor in zebrafish (Danio rerio) testis. Reproduction 136, 225-234.

Diotel, N., Do Rego, J. L., Anglade, I., Vaillant, C., Pellegrini, E., Gueguen, M. M., Mironov, S., Vaudry, H., and Kah, O. (2011a). Activity and expression of steroidogenic enzymes in the brain of adult zebrafish. Eur. J. Neurosci. 34, 45-56.

Diotel, N., Servili, A., Gueguen, MM., Mironov, S., Pellegrini, E., Vaillant, C., Zhu, Y., Kah, O., and Anglade, I. (2011b). Nuclear progesterone receptors are up-regulated by estrogens in neurons and radial glial progenitors in the brain of zebrafish. PLOS ONE 6:11. e28375. doi:10.1371/journal.pone.0028375

Diotel, N., Le Page, Y., Mouriec, K., Tong, S. K., Pellegrini, E., Vaillant, C., Anglade, I., Brion, F., Pakdel, F., Chung, B. C., and Kah, O. (2010a). Aromatase in the brain of teleost fish: expression, regulation and putative functions. Front. Neuroendocrinol. 31, 172-192.

Diotel, N., Vaillant, C., Gueguen, M. M. Mironov, S., Anglade, I., Servili, A., Pellegrini, E., and Kah, O. (2010b). Cxcr4 and $\mathrm{Cxcl} 12$ expression in radial glial cells of the brain of adult zebrafish. J. Comp. Neurol. 518, 4855-4876.

Do Rego, J. L., Seong, J. Y., Burel, D., Leprince, J., Luu-the, V., Tsutsui, K., Tonon, M. C., Pelletier, G. and Vaudry, H. (2009). Neurosteroid biosynthesis: enzymatic pathways and neuroendocrine regulation by neurotransmitters and neuropeptides. Front. Neuroendocrinol. 30, 259-301.

Do-Rego, J. L., Acharjee, S., Seong, J. Y., Galas, L., Alexandre, D., Bizet, P., Burlet, A., Kwon, H. B., Luuthe, V., Pelletier, G., and Vaudry, H. (2006). Vasotocin and mesotocin stimulate the biosynthesis of neurosteroids in the frog brain. J. Neurosci. 26, 6749-6760.

Douard, V., Brunet, F., Boussau, B., Ahrens-Fath, I., Vlaeminck-Guillem, V., Haendler, B., Laudet, V., and Guiguen, Y. (2008). The fate of the duplicated androgen receptor in fishes: a late neofunctionalization event? BMC Evol. Biol. 8, 336. doi:10.1186/1471-2148-8-336

Ekström, P., Johnsson, C. M., and Ohlin, L. M. (2001). Ventricular proliferation zones in the brain of an adult teleost fish and their relation to neuromeres and migration (secondary matrix) zones. J. Comp. Neurol. 436, 92-110.

Forlano, P. M., Deitcher, D. L., Myers, D. A., and Bass, A. H. (2001). Anatomical distribution and cellular basis for high levels of aromatase activity in the brain of teleost fish: aromatase enzyme and mRNA expression identify glia as source. J. Neurosci. 21 , 8943-8955.

Forlano, P. M., Marchaterre, M., Deitcher, D. L., and Bass, A. H. (2010). Distribution of androgen receptor mRNA expression in vocal, auditory, and neuroendocrine circuits in a teleost fish. J. Comp. Neurol. 518, 493-512.

Forlano, P. M., Schlinger, B. A., and Bass, A. H. (2006). Brain aromatase: new lessons from nonmammalian model systems. Front. Neuroendocrinol. 27, 247-274.

Gonzalez, A., and Piferrer, F. (2002). Characterization of aromatase activity in the sea bass: effects of temperature and different catalytic properties of brain and ovarian homogenates and microsomes. $J$ Exp. Zool. 293, 500-510.
Gonzalez, A., and Piferrer, F. (2003). Aromatase activity in the European sea bass (Dicentrarchus labrax L.) brain. Distribution and changes in relation to age, sex, and the annual reproductive cycle. Gen. Comp. Endocrinol. 132, 223-230.

Gorelick, D. A., Watson, W., and Halpern, M. E. (2008). Androgen receptor gene expression in the developing and adult zebrafish brain. Dev. Dyn. 237, 2987-2995.

Goto-Kazeto, R., Kight, K. E., Zohar, Y., Place, A. R., and Trant, J. M. (2004). Localization and expression of aromatase mRNA in adult zebrafish. Gen. Comp. Endocrinol. 139, 72-84.

Greytak, S. R., Champlin, D., and Callard, G. V. (2005). Isolation and characterization of two cytochrome P450 aromatase forms in killifish (Fundulus heteroclitus): differential expression in fish from polluted and unpolluted environments. Aquat. Toxicol. 71, 371-389.

Halm, S., Kwon, J. Y., Rand-Weaver, M., Sumpter, J. P., Pounds, N. Hutchinson, T. H., and Tyler, C. R. (2003). Cloning and gene expression of P450 17alpha-hydroxylase,17,20lyase cDNA in the gonads and brain of the fathead minnow Pimephales promelas. Gen. Comp. Endocrinol. 130, 256-266.

Hanna, R. N., Daly, S. C., Pang, Y., Anglade, I., Kah, O., Thomas, P. and Zhu, Y. (2010). Characterization and expression of the nuclear progestin receptor in zebrafish gonads and brain. Biol. Reprod. 82, 112-122.

Hsu, H. J., Hsiao, P., Kuo, M. W., and Chung, B. C. (2002). Expression of zebrafish cypllal as a maternal transcript and in yolk syncytial layer. Gene Expr. Patterns 2, 219-222.

Hu, M. C., Hsu, H. J., Guo, I. C., and Chung, B. C. (2004). Function of Cypllal in animal models. Mol. Cell. Endocrinol. 215, 95-100.

Ijiri, S., Kazeto, Y., Lokman, P. M., Adachi, S., and Yamauchi, K. (2003). Characterization of a cDNA encoding $\mathrm{P}-450$ aromatase (CYP19) from Japanese eel ovary and its expression in ovarian follicles during induced ovarian development. Gen. Comp. Endocrinol. 130, 193-203.

Ings, J. S., and Van Der Kraak, G. J. (2006). Characterization of the mRNA expression of StAR and steroidogenic enzymes in zebrafish ovarian follicles. Mol. Reprod. Dev. 73, 943-954. 
Jorgensen, A., Andersen, O., Bjerregaard, P., and Rasmussen, L. J. (2007). Identification and characterisation of an androgen receptor from zebrafish Danio rerio. Comp. Biochem. Physiol. C Toxicol. Pharmacol. 146, 561-568.

Kah, O., Pellegrini, E., Mouriec, K., Diotel, N., Anglade, I., Vaillant, C., Thieulant, M. L., Tong, S. K., Brion, F., Chung, B. C., and Pakdel, F. (2009). Oestrogens and neurogenesis: new functions for an old hormone. Lessons from the zebrafish. J. Soc. Biol. 203, 29-38.

Kazeto, Y., Ijiri, S., Matsubara, H., Adachi, S., and Yamauchi, K. (2000). Cloning of 17beta-hydroxysteroid dehydrogenase-I cDNAs from Japanese eel ovary. Biochem. Biophys. Res. Commun. 279, 451-456.

Kishida, M., and Callard, G. V. (2001). Distinct cytochrome P450 aromatase isoforms in zebrafish (Danio rerio) brain and ovary are differentially programmed and estrogen regulated during early development. Endocrinology 142, 740-750.

Kwon, J. Y., Mcandrew, B. J., and Penman, D. J. (2001). Cloning of brain aromatase gene and expression of brain and ovarian aromatase genes during sexual differentiation in genetic male and female Nile tilapia Oreochromis niloticus. Mol. Reprod. Dev. 59, 359-370.

Lam, C. S., Marz, M., and Strahle, U. (2009). GFAP and nestin reporter lines reveal characteristics of neural progenitors in the adult zebrafish brain. Dev. Dyn. 238, 475-486.

Lavaque, E., Sierra, A., Azcoitia, I., and Garcia-Segura, L. M. (2006). Steroidogenic acute regulatory protein in the brain. Neuroscience 138, 741-747.

Le Page, Y., Diotel, N., Vaillant, C., Pellegrini, E., Anglade, I., Merot, Y., and Kah, O. (2010). Aromatase, brain sexualization and plasticity: the fish paradigm. Eur. J. Neurosci. 32, 2105-2115.

Le Page, Y., Menuet, A., Kah, O., and Pakdel, F. (2008). Characterization of a cis-acting element involved in cell-specific expression of the zebrafish brain aromatase gene. Mol. Reprod. Dev. 75, 1549-1557.

Le Page, Y., Scholze, M., Kah, O., and Pakdel, F. (2006). Assessment of xenoestrogens using three distinct estrogen receptors and the zebrafish brain aromatase gene in a highly responsive glial cell system. Environ. Health Perspect. 114, 752-758.
Lieberman, S., Greenfield, N. J., and Wolfson, A. (1984). A heuristic proposal for understanding steroidogenic processes. Endocr. Rev. 5, 128-148.

Lieberman, S., and Lin, Y. Y. (2001). Reflections on sterol sidechain cleavage process catalyzed by cytochrome P450(scc). J. Steroid Biochem. Mol. Biol. 78, 1-14.

Lin, A. C., and Holt, C. E. (2008). Function and regulation of local axonal translation. Curr. Opin. Neurobiol. $18,60-68$.

Lin, H. K., Jez, J. M., Schlegel, B. P., Peehl, D. M., Pachter, J. A., and Penning, T. M. (1997). Expression and characterization of recombinant type 23 alpha-hydroxysteroid dehydrogenase (HSD) from human prostate: demonstration of bifunctional 3 alpha/17 beta-HSD activity and cellular distribution. Mol. Endocrinol. 11, 1971-1984.

Linard, B., Anglade, I., Corio, M., Navas, J. M., Pakdel, F., Saligaut, C., and Kah, O. (1996). Estrogen receptors are expressed in a subset of tyrosine hydroxylase-positive neurons of the anterior preoptic region in the rainbow trout. Neuroendocrinology 63, 156-165.

Liu, X., Zhu, P., Sham, K. W., Yuen, J. M., Xie, C., Zhang, Y., Liu, Y., Li, S., Huang, X., Cheng, C. H., and Lin, H. (2009). Identification of a membrane estrogen receptor in zebrafish with homology to mammalian GPER and its high expression in early germ cells of the testis. Biol. Reprod. 80, 1253-1261.

Lyssimachou, A., and Arukwe, A. (2007). Alteration of brain and interrenal StAR protein, $\mathrm{P} 450 \mathrm{scc}$, and Cyp11beta mRNA levels in Atlantic salmon after nominal waterborne exposure to the synthetic pharmaceutical estrogen ethinylestradiol. $J$. Toxicol. Environ. Health Part A 70, 606-613.

Martin, K. C., and Zukin, R. S. (2006). RNA trafficking and local protein synthesis in dendrites: an overview. J. Neurosci. 26, 7131-7134.

März, M., Chapouton, P., Diotel, N., Vaillant, C., Hesl, B., Takamiya, M., Lam, C. S., Kah, O., Bally-Cuif, L., and Strahle, U. (2010). Heterogeneity in progenitor cell subtypes in the ventricular zone of the zebrafish adult telencephalon. Glia 58, 870-888.

Mathieu, M., Mensah-Nyagan, A. G., Vallarino, M., Do-Rego, J. L., Beaujean, D., Vaudry, D., Luu-the, V., Pelletier, G., and Vaudry, H. (2001). Immunohistochemical localization of 3 beta-hydroxysteroid dehydrogenase and 5 alpha-reductase in the brain of the African lungfish Protopterus annectens. J. Comp. Neurol. 438, 123-135.

Mayer, I., Borg, B., Berglund, I., and Lambert, J. G. (1991). Effects of castration and androgen treatment on aromatase activity in the brain of mature male Atlantic salmon (Salmo salar L.) parr. Gen. Comp. Endocrinol. 82, 86-92.

Mellon, S. H., Griffin, L. D., and Compagnone, N. A. (2001). Biosynthesis and action of neurosteroids. Brain Res. Brain Res. Rev. 37, 3-12.

Menuet, A., Anglade, I., Le Guevel, R., Pellegrini, E., Pakdel, F., and Kah, O. (2003). Distribution of aromatase mRNA and protein in the brain and pituitary of female rainbow trout: comparison with estrogen receptor alpha. J. Comp. Neurol. 462, 180-193.

Menuet, A., Pellegrini, E., Anglade, I., Blaise, O., Laudet, V., Kah, O., and Pakdel, F. (2002). Molecular characterization of three estrogen receptor forms in zebrafish: binding characteristics, transactivation properties, and tissue distributions. Biol. Reprod. 66 1881-1892.

Menuet, A., Pellegrini, E., Brion, F., Gueguen, M. M., Anglade, I., Pakdel, F., and Kah, O. (2005). Expression and estrogen-dependent regulation of the zebrafish brain aromatase gene. J. Comp. Neurol. 485 , 304-320.

Miller, W. L., Auchus, R. J., and Geller, D. H. (1997). The regulation of 17, 20 lyase activity. Steroids 62, 133-142.

Mindnich, R., and Adamski, J. (2007). Functional aspects of 17betahydroxysteroid dehydrogenase 1 determined by comparison to a closely related retinol dehydrogenase. J. Steroid Biochem. Mol. Biol. 104, 334-339.

Mindnich, R., and Adamski, J. (2009). Zebrafish 17beta-hydroxysteroid dehydrogenases: an evolutionary perspective. Mol. Cell. Endocrinol. 301, 20-26.

Mindnich, R., Deluca, D., and Adamski, J. (2004). Identification and characterization of 17 beta-hydroxysteroid dehydrogenases in the zebrafish, Danio rerio. Mol. Cell. Endocrinol. 215, 19-30.

Mindnich, R., Haller, F., Halbach, F., Moeller, G., Hrabe De Angelis, M., and Adamski, J. (2005). Androgen metabolism via 17betahydroxysteroid dehydrogenase type 3 in mammalian and non-mammalian vertebrates: comparison of the human and the zebrafish enzyme. J. Mol. Endocrinol. $35,305-316$.
Mindnich, R., Hrabe De Angelis, M., and Adamski, J. (2007). Functional genome analysis indicates loss of 17beta-hydroxysteroid dehydrogenase type 2 enzyme in the zebrafish. J. Steroid Biochem. Mol. Biol. 103, 35-43.

Mouriec, K., Gueguen, M. M., Manuel, C., Percevault, F., Thieulant, M. L., Pakdel, F., and Kah, O. (2009a). Androgens upregulate cyp19alb (aromatase B) gene expression in the brain of zebrafish (Danio rerio) through estrogen receptors. Biol. Reprod. 80, 889-896.

Mouriec, K., Lareyre, J. J., Tong, S. K., Le Page, Y., Vaillant, C., Pellegrini, E., Pakdel, F., Chung, B. C., Kah, O., and Anglade, I. (2009b). Early regulation of brain aromatase (cyp19alb) by estrogen receptors during zebrafish development. Dev. Dyn. 238, 26412651.

Mouriec, K., Pellegrini, E., Anglade, I., Menuet, A., Adrio, F., Thieulant, M L., Pakdel, F., and Kah, O. (2008). Synthesis of estrogens in progenitor cells of adult fish brain: evolutive novelty or exaggeration of a more general mechanism implicating estrogens in neurogenesis? Brain Res. Bull. 75, 274-280.

Munchrath, L. A., and Hofmann, H. A (2010). Distribution of sex steroid hormone receptors in the brain of an African cichlid fish, Astatotilapia burtoni. J. Comp. Neurol. 518, 3302-3326.

Nagarajan, G., Tsai, Y. J., Chen, C. Y., and Chang, C. F. (2011). Developmental expression of genes involved in neural estrogen biosynthesis and signaling in the brain of the orange-spotted grouper Epinephelus coioides during gonadal sex differentiation. J Steroid Biochem. Mol. Biol. 127, 155-166.

Navas, J. M., Anglade, I., Bailhache, T., Pakdel, F., Breton, B., Jego, P., and Kah, O. (1995). Do gonadotrophinreleasing hormone neurons express estrogen receptors in the rainbow trout? A double immunohistochemical study. J. Comp. Neurol. 363, 461-474.

Oakley, A. E., Clifton, D. K., and Steiner, R. A. (2009). Kisspeptin signaling in the brain. Endocr. Rev. 30, 713-743.

Pakdel, F., Petit, F., Anglade, I., Kah, O., Delaunay, F., Bailhache, T., and Valotaire, Y. (1994). Overexpression of rainbow trout estrogen receptor domains in Escherichia coli: characterization and utilization in the production of antibodies for immunoblotting and immunocytochemistry. Mol. Cell. Endocrinol. 104, 81-93. 
Pasmanik, M., and Callard, G. V. (1985). Aromatase and 5 alpha-reductase in the teleost brain, spinal cord, and pituitary gland. Gen. Comp. Endocrinol. 60, 244-251.

Pasmanik, M., and Callard, G. V. (1988). Changes in brain aromatase and 5 alpha-reductase activities correlate significantly with seasonal reproductive cycles in goldfish (Carassius auratus). Endocrinology 122, 1349-1356.

Pasmanik, M., Schlinger, B. A., and Callard, G. V. (1988). In vivo steroid regulation of aromatase and 5 alphareductase in goldfish brain and pituitary. Gen. Comp. Endocrinol. 71, 175-182.

Pellegrini, E., Menuet, A., Lethimonier, C., Adrio, F., Gueguen, M. M., Tascon, C., Anglade, I., Pakdel, F., and Kah, O. (2005). Relationships between aromatase and estrogen receptors in the brain of teleost fish. Gen. Comp. Endocrinol. 142, 60-66.

Pellegrini, E., Mouriec, K., Anglade, I., Menuet, A., Le Page, Y., Gueguen, M. M., Marmignon, M. H., Brion, F., Pakdel, F., and Kah, O. (2007). Identification of aromatase-positive radial glial cells as progenitor cells in the ventricular layer of the forebrain in zebrafish. J. Comp. Neurol. 501, 150-167.

Peltoketo, H., Luu-the, V., Simard, J., and Adamski, J. (1999). 17betahydroxysteroid dehydrogenase (HSD)/17-ketosteroid reductase (KSR) family; nomenclature and main characteristics of the 17HSD/KSR enzymes. J. Mol. Endocrinol. 23, 1-11.

Piferrer, F., and Blazquez, M. (2005). Aromatase distribution and regulation in fish. Fish Physiol. Biochem. 31, 215-226.

Pouso, P., Quintana, L., Bolatto, C., and Silva, A. C. (2010). Brain androgen receptor expression correlates with seasonal changes in the behavior of a weakly electric fish, Brachyhypopomus gauderio. Horm. Behav. 58, 729-736.

Raju, C. S., Goritz, C., Nord, Y., Hermanson, O., Lopez-Iglesias, C., Visa, N., Castelo-Branco, G., and Percipalle, P. (2008). In cultured oligodendrocytes the A/B-type hnRNP CBF-A accompanies MBP mRNA bound to mRNA trafficking sequences. Mol. Biol. Cell 19, 3008-3019.

Ravi, V., and Venkatesh, B. (2008). Rapidly evolving fish genomes and teleost diversity. Curr. Opin. Genet. Dev. 18, 544-550.
Russell, D. W., and Wilson, J. D. (1994). Steroid 5 alpha-reductase: two genes/two enzymes. Annu. Rev. Biochem. 63, 25-61.

Sakamoto, H., Ukena, K., and Tsutsui, K. (2001). Activity and localization of 3beta-hydroxysteroid dehydrogenase/Delta5-Delta4isomerase in the zebrafish central nervous system. J. Comp. Neurol. 439, 291-305.

Schlinger, B. A., Amur-Umarjee, S., Shen, P., Campagnoni, A. T., and Arnold, A. P. (1994). Neuronal and non-neuronal aromatase in primary cultures of developing zebra finch telencephalon. J. Neurosci. 14, 7541-7552.

Schulz, R., and Blum, V. (1991). Extragonadal 17 beta-hydroxysteroid dehydrogenase activity in rainbow trout. Gen. Comp. Endocrinol. 82, 197-205.

Servili, A., Le Page, Y., Leprince, J., Caraty, A., Escobar, S., Parhar, I. S., Seong, J. Y., Vaudry, H., and Kah, O. (2011). Organization of two independent kisspeptin systems derived from evolutionaryancient kiss genes in the brain of zebrafish. Endocrinology 152, 1527-1540.

Simpson, E. R., and Davis, S. R. (2001). Minireview: aromatase and the regulation of estrogen biosynthesis - some new perspectives. Endocrinology 142, 4589-4594.

Sinchak, K., Mills, R. H., Tao, L., Lapolt, P., Lu, J. K., and Micevych, P. (2003). Estrogen induces de novo progesterone synthesis in astrocytes. Dev. Neurosci. 25, 343-348.

Smolinsky, A. N., Doughman, J. M., Kratzke, L. T., and Lassiter, C. S. (2010). Zebrafish (Danio rerio) androgen receptor: sequence homology and up-regulation by the fungicide vinclozolin. Comp. Biochem. Physiol. C Toxicol. Pharmacol. 151, 161-166.

Sperry, T. S., and Thomas, P. (1999). Characterization of two nuclear androgen receptors in Atlantic croaker: comparison of their biochemical properties and binding specificities. Endocrinology 140, 1602-1611.

Steinke, D., Hoegg, S., Brinkmann, H., and Meyer, A. (2006). Three rounds $(1 \mathrm{R} / 2 \mathrm{R} / 3 \mathrm{R})$ of genome duplications and the evolution of the glycolytic pathway in vertebrates. BMC Biol. 4 , 16. doi:10.1186/1741-7007-4-16

Strobl-Mazzulla, P. H., Lethimonier, C., Gueguen, M. M., Karube, M., Fernandino, J. I., Yoshizaki, G., Patino,
R., Strussmann, C. A., Kah, O. and Somoza, G. M. (2008). Brain aromatase (Cyp19A2) and estrogen receptors, in larvae and adult pejerrey fish Odontesthes bonariensis: neuroanatomical and functional relations. Gen. Comp. Endocrinol. 158, 191-201.

Strobl-Mazzulla, P. H., Nunez, A., Pellegrini, E., Gueguen, M. M., Kah, O. and Somoza, G. M. (2010). Progenitor radial cells and neurogenesis in pejerrey fish forebrain. Brain Behav. Evol. 76, 20-31.

Takeo, J., and Yamashita, S. (1999). Two distinct isoforms of cDNA encoding rainbow trout androgen receptors. J. Biol. Chem. 274, 5674-5680.

Tanaka, M., Telecky, T. M., Fukada, S., Adachi, S., Chen, S., and Nagahama, Y. (1992). Cloning and sequence analysis of the cDNA encoding P-450 aromatase (P450arom) from a rainbow trout (Oncorhynchus mykiss) ovary; relationship between the amount of P450arom mRNA and the production of oestradiol-17 beta in the ovary. J. Mol. Endocrinol. 8, 53-61.

Timmers, R. J., and Lambert, J. G. (1987). Measurement of aromatase activity in the brain of the African catfish, Clarias gariepinus - a comparison of two assay methods. Comp. Biochem. Physiol. B $88,453-456$.

Timmers, R. J., Lambert, J. G., Peute, J., Vullings, H. G., and Van Oordt, P. G. (1987). Localization of aromatase in the brain of the male African catfish, Clarias gariepinus (Burchell), by microdissection and biochemical identification. J. Comp. Neurol. 258, 368-377.

Tomy, S., Wu, G. C., Huang, H. R., and Chang, C. F. (2009). Agedependent differential expression of genes involved in steroid signalling pathway in the brain of protandrous black porgy, Acanthopagrus schlegeli. Dev. Neurobiol. 69, 299-313.

Tomy, S., Wu, G. C., Huang, H. R., Dufour, S., and Chang, C. F. (2007). Developmental expression of key steroidogenic enzymes in the brain of protandrous black porgy fish, Acanthopagrus schlegeli. J. Neuroendocrinol. 19, 643-655.

Tong, S. K., Mouriec, K., Kuo, M. W., Pellegrini, E., Gueguen, M. M., Brion, F., Kah, O., and Chung, B. C. (2009). A cyp19a1b-GFP (aromatase B) transgenic zebrafish line that expresses GFP in radial glial cells. Genesis 47 , 67-73.
Tsutsui, K., and Ukena, K. (1999). Neurosteroids in the cerebellar Purkinje neuron and their actions (review). Int. J. Mol. Med. 4, 49-56.

Tsutsui, K., Ukena, K., Takase, M. Kohchi, C., and Lea, R. W. (1999). Neurosteroid biosynthesis in vertebrate brains. Comp. Biochem. Physiol. CPharmacol. Toxicol. Endocrinol. 124, 121-129.

Valle, L. D., Ramina, A., Vianello, S., Belvedere, P., and Colombo, L. (2002). Cloning of two mRNA variants of brain aromatase cytochrome $\mathrm{P} 450$ in rainbow trout (Oncorhynchus mykiss Walbaum). J. Steroid Biochem. Mol. Biol. 82, 19-32.

Vizziano-Cantonnet, D., Anglade, I. Pellegrini, E., Gueguen, M. M., Fostier, A., Guiguen, Y., and Kah, O. (2011). Sexual dimorphism in the brain aromatase expression and activity, and in the central expression of other steroidogenic enzymes during the period of sex differentiation in monosex rainbow trout populations. Gen. Comp. Endocrinol. 170, 346-355.

Wang, Y., and Ge, W. (2004). Cloning of zebrafish ovarian P450c17 (CYP17, 17alpha-hydroxylase/17, 20-lyase) and characterization of its expression in gonadal and extra-gonadal tissues. Gen. Comp. Endocrinol. 135, 241-249.

Yu, H., Cheng, H., Guo, Y., Xia, L., and Zhou, R. (2003). Alternative splicing and differential expression of P450c17 (CYP17) in gonads during sex transformation in the rice field eel. Biochem. Biophys. Res. Commun. 307, 165-171.

Zhang, Y., Zhang, W., Yang, H., Zhou, W., Hu, C., and Zhang, L. (2008). Two cytochrome P450 aromatase genes in the hermaphrodite rice field eel Monopterus albus: mRNA expression during ovarian development and sex change. J. Endocrinol. 199, 317-331.

Zhang, Y., Zhang, W., Zhang, L., Zhu, T., Tian, J., Li, X., and Lin, $\mathrm{H}$ (2004). Two distinct cytochrome $\mathrm{P} 450$ aromatases in the orangespotted grouper (Epinephelus coioides): cDNA cloning and differential mRNA expression. $J$. Steroid Biochem. Mol. Biol. 92, $39-50$.

Zohar, Y., Munoz-Cueto, J. A., Elizur, A., and Kah, O. (2009). Neuroendocrinology of reproduction in teleost fish. Gen. Comp. Endocrinol. $165,438-455$. 
Zwain, I. H., and Yen, S. S. (1999). Neurosteroidogenesis in astrocytes, oligodendrocytes, and neurons of cerebral cortex of rat brain. Endocrinology 140, 3843-3852.

Conflict of Interest Statement: The authors declare that the research was conducted in the absence of any commercial or financial relationships that could be construed as a potential conflict of interest.

Received: 16 November 2011; paper pending published: 28 November 2011; accepted: 30 November 2011; published online: 19 December 2011.
Citation: Diotel N, Do Rego J-L, Anglade I, Vaillant C, Pellegrini E, Vaudry $H$ and Kah $O$ (2011) The brain of teleost fish, a source, and a target of sexual steroids. Front. Neurosci. 5:137. doi: 10.3389/fnins.2011.00137

This article was submitted to Frontiers in Neuroendocrine Science, a specialty of Frontiers in Neuroscience.
Copyright (C) 2011 Diotel, Do Rego, Anglade, Vaillant, Pellegrini, Vaudry and Kah. This is an open-access article distributed under the terms of the Creative Commons Attribution Non Commercial License, which permits noncommercial use, distribution, and reproduction in other forums, provided the original authors and source are credited. 